\title{
POLITICAL COMPETITION AND CONVERGENCE TO FUNDAMENTALS: WITH APPLICATION TO THE POLITICAL BUSINESS CYCLE AND THE SIZE OF GOVERNMENT
}

\author{
J. STEPHEN FERRIS \\ SOO-BIN PARK \\ STANLEY L. WINER
}

\section{CESIFO WORKING PAPER NO. 1646 \\ CATEgory 2: Public CHOICE \\ JANUARY 2006}

An electronic version of the paper may be downloaded

- from the SSRN website:

www.SSRN.com

- from the CESifo website: www.CESifo-group.de 


\title{
POLITICAL COMPETITION AND CONVERGENCE TO FUNDAMENTALS: WITH APPLICATION TO THE POLITICAL BUSINESS CYCLE AND THE SIZE OF GOVERNMENT
}

\begin{abstract}
We address the problem of how to investigate whether economics, or politics, or both, matter in the explanation of public policy. The problem is first posed in a particular context by uncovering a political business cycle (using Canadian data for 130 years) and by taking up the challenge to make this fact meaningful by finding a transmission mechanism through actual public choices. Since the cycle is in real growth, and it is reasonable to suppose that public expenditure would be involved, the central task then is to investigate the role of (partisan and opportunistic) political factors, as opposed to economic fundamentals, in the evolution of government size.

We proceed by asking whether the data allow us to distinguish between the convergence and the nonconvergence hypotheses. Convergence means that political competition forces public spending to converge in the long run to a level dictated by endowments, tastes and technology. Nonconvergence is taken to mean that political factors other than the degree of political competition prevent convergence to that long run. The general idea here, one that may be applied in any situation where the key issue is the role of economics versus politics over time, is that an overtly political factor can be said to play a distinct role in the evolution of public choices if it can be shown to lead to departures from a dynamic path defined by the evolution of economic fundamentals in a competitive political system.
\end{abstract}

JEL Code: H1, H3, H5.

Keywords: public expenditure, size of government, long run versus short run, opportunism, partisanship, political competition, cointegration.
J. Stephen Ferris
stephen_ferris@carleton.ca
Soo-Bin Park
soo-bin_park@carleton.ca
Stanley L. Winer
stan_winer@carleton.ca
all authors: Department of Economics
1125 Colonel By Drive
Carleton University
Ottawa Ontario, Canada, K1S $5 B 6$

December 14, 2005

An earlier version of this paper was presented at the Public Choice Society Meetings in Baltimore, March 2004, the European Public Choice Meetings in Durham U.K., April 2005, the IIPF Congress in Jeju South Korea in August 2005, at the Universities of Bocconi, Catania, Pisa and Turin in June 2005 and at the National University of Cordoba in September 2005. Our thanks to Christian Bjornskov, Giorgio Brosio, Mario Ferrero, Vincenzo Galasso, Emma Galli, Ernesto Rezk, Carla Marchese, Fabio Padovano, Paola Profeta and Anna Rubinchik-Pessach for helpful comments. Support provided to Winer by the International Center for Economic Research in Turin and the Department of Economics of the University of Turin is gratefully acknowledged. 


\section{Introduction: Politics versus Economics in the Evolution of Macroeconomic Outcomes and The Size of Government}

In this paper we address the problem of how to investigate whether economics, or politics, or both, matter in the explanation of public policy. To generate specificity, we pose the problem in a particular context by first investigating whether a political business cycle can be found in annual Canadian data covering almost the entire history of the modern state from 1870 to $2000 .{ }^{1}$ After finding substantial evidence of a political cycle in real output (less so for inflation), we take up the challenge of Bartels and Brady (2003) to make this stylized fact more meaningful by searching for its transmission mechanism in actual public choices. ${ }^{2}$ Since the observed political business cycle is in aggregate real growth, and it is reasonable to suppose that public expenditure of the central government would be involved, we focus on the problem of separating the role of (partisan and opportunistic) political factors, as opposed to economics, in the evolution of government size.

To test whether political factors can explain at least part of the quantitative change in government size needed to produce the observed political cycles, we consider whether the data allow us to distinguish between two competing hypotheses: the economic convergence and the nonconvergence hypotheses. By economic convergence we mean that political competition forces public expenditure to converge on the level dictated by endowments, tastes and technology - that is, on the level determined by economic 'fundamentals' alone. In contrast, nonconvergence is taken to mean that political factors other than the degree of political competition prevent convergence to that long run level. The general idea that we implement, one that may be applied in any situation where the key issue is the role of economics versus politics, is that any kind of overtly political factor can be said to play a distinct role in the evolution of public choices if it can be shown to lead to departures from a dynamic path defined by the evolution of economic fundamentals in a competitive political system. ${ }^{3}$

We use cointegration and error correction modeling to identify as nonconvergent situations where at least part of long run government size, or short run variations about that long run, can be explained by the partisan nature of politics (which party is in power, whether the party in power had a majority or not) or by the opportunistic nature of political competition (the specific timing of events during the electoral cycle). ${ }^{4}$ Although nonconvergence could arise in either the long or the short run, and we test for both,

1. Many authors, including Nordhaus (1975), Hibbs (1977), Schneider and Pommerehne (1980) and Alesina and Roubini and Cohen (1997) among others have argued that the time series of many countries are consistent with the types of macroeconomic activity predicted by opportunistic or partisan political business cycle theories. Implicitly these authors argue for the centrality of distinctly political determinants of aggregate economic outcomes (Bartels and Brady, 2003).

2. After reporting on the effect of partisan differences in the US, Bartels and Brady (p.159) write, "(o)ne might imagine economists reacting to Hibb's work by launching a major effort to understand the processes by which partisan politics shapes economic policies and performance. Unfortunately, no such effort seems to be forthcoming.."

3. By discussing this general issue in the context of the political business cycle literature and by investigating government expenditure as the possible transmission mechanism, we have of course narrowed the list of economic and political factors that may be relevant.

4. See Engel and Granger 1987 and Johansen 1991. We initially use the Engle-Granger rather than Johansen approach in implementing the convergence hypothesis because we are interested in the long run equilibrium relationship running to government size from certain economic and political factors. In this context, we have less interest in the structure of the cointegrating relationships running among the full set of variables used to explain government size. However, we also apply the Johansen method to consider the robustness of our results and to complement the Engel-Granger approach. 
our focus on political business cycles leads us to be concerned primarily with the short run.

From the perspective of the political business cycle literature, it should be noted that our implementation of the convergence hypothesis using cointegration and error correction requires explicit modeling of the long run processes governing public choices. This permits us to improve upon the current use in much of the empirical political cycle literature of Hodrick-Prescott filtered residuals to test the short run hypotheses on which this literature focuses. That is, the longer run time path of public choices may be highly volatile if the underlying economic environment is, allowing a simple deterministic method of detrending to hide as much as it reveals (see, for example, Canova 1998). Moreover, implementation of a dynamic model permits us to deal with possible interconnections between economic fundamentals in the longer run and political factors that play a role over shorter horizons, interconnections which may arise because of intertemporal optimization by voters and by political parties. ${ }^{5}$

While the methodology we use to study the contributions of economics and politics could be applied to any competitive political system, Canada has characteristics that make it a particularly interesting case study. First, there exist good data for the entire history of its modern state in which the basic nature of the majoritarian, parliamentary system at the center has remained essentially unaltered. Second, Canada's economy is highly integrated with the much larger economy of United States, making it relatively easy to control for important variations in economic activity that must have arisen independently of domestic political events. ${ }^{6}$

Finally, the Canadian case is interesting because there is little consensus on the nature of the empirical relationships among political factors and macroeconomic aggregates. ${ }^{7}$ Winer (1986a), using quarterly data, provided early evidence linking politics and policy by finding two way causality running between monetary growth and Gallup Poll data over the post 1970 period of flexible exchange rates (but not under the fixed rates of 1962-1970). ${ }^{8}$ More recently Reid (1998), using pooled time series, cross section data from Canada's provinces (1962-1992) found evidence of an electoral budget cycle, but not of the

5. Haynes and Stone (1990) identify the interconnection between short and long runs (in the United States) as issue that needs to be addressed empirically when considering political business cycles. We agree. Rational political agents will always plan on carrying out programs that extend over time if only because political competition forces them to listen to voters who optimize over time. Political parties and (brand name) reputation insure that such plans last well beyond the current electoral period.

6. In so doing, we take account of the role of the exchange rate mechanism.

7. As in most developed countries, there is also a substantial history of controversy over the appropriateness of different dimensions of macroeconomic policy and the links between policy and economic outcomes. For example, the Royal Commission on Banking and Finance (1964) considered the use of fiscal versus monetary policy as the appropriate instrument for federal stabilization policy (Reuber, 1978). While the overwhelming Keynesian tenor of that report gave support to a post-WWII period of more intensive reliance on fiscal policy (investigated in a companion paper, Ferris and Winer 2003), the same time period also witnessed the beginnings of the monetarist counter revolution by Canadian economists like Harry Johnson, Thomas Courchene and David Laidler. As a result of these debates and the changing fortunes of their different viewpoints, there is reason to believe that federal governments in Canada were encouraged to vary the nature of macroeconomic policy, and likely did, giving rise to a varied history of macroeconomic policy choices that provides fertile ground for the empirical applications in this paper.

8. Winer's evidence for political cycles in monetary growth - using answers to the Gallup poll question: "if there was an election today, which party would you vote for" - is relatively weak, arising only in high frequency quarterly data under flexible exchange rates, and explaining only a small percentage of the overall variation in monetary growth. 
opportunistic timing of elections. Kneebone and McKenzie (2001), on the other hand, find evidence consistent with opportunism but not with partisanship. At the federal level, Heckelman (2002) tested for the presence of an asymmetric incumbency effect on growth between 1965 and 1996 and found evidence consistent only with a temporary symmetric effect on the level but not the rate of growth of output.

Over a slightly longer time period (1961 to 1998), Kneebone and McKenzie (1999) used a HodrickPrescott filter to control for longer run factors behind federal and provincial government deficits and found evidence of 'pronounced' opportunism and 'strong evidence' of partisanship at all levels of government and in all stages of the fiscal structure. This stands in strong contrast to the findings of Serletis and Afxentiou (1998) who find, using annual data for 1926 to 1994, no evidence of any regularity arising between a set of Hodrick-Prescott filtered policy target variables (such as output and unemployment) and a set of similarly filtered government policy instruments (such as government consumption and government investment). ${ }^{9}$

We begin our analysis in the next section with a quick look at the history of real growth and inflation in Canada followed by a test for the existence of traditionally defined political cycles. After finding evidence of a quantitatively important political cycle in real growth, we turn in section three to a discussion of the methodology used to consider whether variations in government size could have been the mechanism generating these observed results. Section four examines the evidence for a long run relationship between a set of economic fundamentals - including the degree of political competition - and the relative size of federal non-interest government expenditure and then tests for whether overtly political factors form part of that relationship. Section five complements this analysis by testing for the presence of political variables reflecting opportunism and partisanship in the implied short run adjustment process. After using simulation to further explore the importance of political competition to our findings, a concluding section summarizes and draws implications for future research. Data sources are presented in an Appendix.

\section{Are there Political Cycles in Annual Canadian Macroeconomic Data?}

Figure 1 presents the dependent variables used to test for opportunistic and partisan influences on macroeconomic outcomes. The outcomes we consider are annual real growth (GROWTH) measured as the rate of growth rate of real Gross National Product (GNP), and inflation (INFLATION) measured by the rate of change of the GNP deflator. ${ }^{10}$ (Descriptive statistics for these economic variables as well as for other economic factors introduced below are found in Table 1a.) The figure shows that both series exhibit somewhat more variability before 1945 than after and that the correlation between growth and inflation has changed with the decades. ${ }^{11}$

[Figure 1]

9. Further discussion of the political business cycle literature is provided below.

10. The rate of unemployment is not available before the 1920's and may not in any case be consistently measured before and after 1945. It is not considered here.

11. The standard deviation of the inflation rate falls from 5.24 over the 1870 to 1938 time period to 3.26 between 1945 and 2000. Over the same periods, the standard deviation of the growth rate falls from 6.17 to 2.73. The correlation coefficient for inflation and real growth over the whole sample period is 0.127 . 
Figure 1

Growth of Real GNP and the Rate of Inflation, Canada 1870-2000

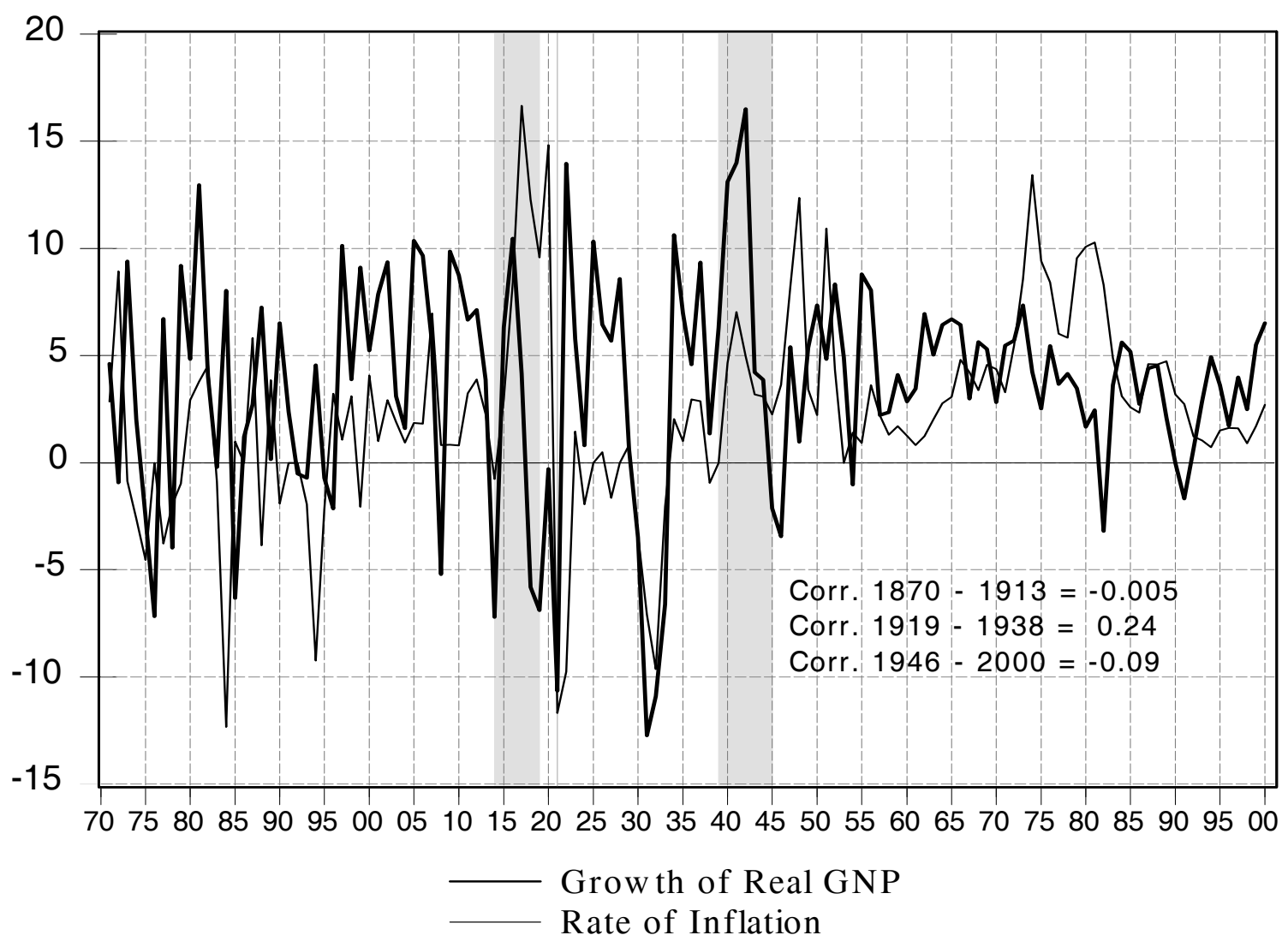

Before we can assess whether political factors explain variations in these measures of macroeconomic performance, it is important to account for variations in output and inflation that have arisen for reasons that are exogenous to domestic electoral politics. Because Canada's political choices have little effect on the economic performance of Canada's major trading partner, USGROWTH, the rate of growth of the U.S. Index of Industrial Production, and USINFLATION, the rate of growth of the U.S. GDP price deflator, are used as controls for the important nonpolitical forces shaping the Canadian economy.

Traditional opportunistic political theories argue that incumbent political parties use their control over government to gain votes opportunistically by increasing aggregate demand in the period immediately prior to each election (Nordhaus, 1975). ${ }^{12}$ This is independent of the ideology of the party in power and is observable through faster rates of real growth and/or higher inflation rates in the period leading into each election. Rational opportunistic theories, on the other hand, rely on the Lucas critique to argue that

12. See Alesina, Roubini, and Cohen (1997, particularly pages 36 and 62) for a convenient summary of opportunistic and partisan political business hypotheses. Haynes and Stone (1990) suggest that partisan and opportunistic effects may not be separable, where interdependence can be tested for with interaction terms. However, our experimentation produced no instances where such interaction was significant in our data. The second issue pointed to by Haynes and Stone - that political cycles may persist over time - is allowed for here and below via the error-correction methodology as we have pointed out above. 
government spending needs to be unanticipated to affect aggregate demand. ${ }^{13}$ Hence rational opportunistic theories suggest that there will be no pre-election boom. To test whether the data are consistent with traditional (or rational) opportunism, we look for a positive (zero) effect of ELECTIONYEAR lagged on either GROWTH or INFLATION. ${ }^{14}$ Descriptive statistics for this opportunistic variable and for the other political factors discussed below are found in Table 1b. All of these variables are stationary in levels.

Partisan political theories, following Hibbs (1977) and others, suggest that the major political party on the left - in Canada, the Liberal Party (indicated by the one-zero dummy variable LIBERAL) - spends more when in power than will their more Conservative alternative (1- LIBERAL). Hence the test for traditional partisanship is a positive sign on the coefficient for LIBERAL. Once again, however, any predictable policy should be anticipated and incorporated into behavior, so that rational partisan political theories refine the hypothesis by arguing that only as long as the electoral outcome is uncertain can the realization of a more liberal political party victory generate (unexpected) boosts to aggregate output or inflation (Alesina, 1987). The size of that effect will depend upon: (a) the degree of surprise in the election result; and (b) the passage of time since the election, as the actual electoral outcome is incorporated into individual expectations.

To test the rational partisanship hypothesis we must then account for both the degree of surprise in the election result and the ideology of the party winning political power. We assume that the degree of surprise in an election will be inversely related to the ex-post size of the winning majority, on the grounds that large ex-post majorities are more likely to have been foreshadowed during the pre-election period, and we measure the degree of surprise as one minus the fraction of seats won by the winning party, (1-SEATS). The direction of the surprise is incorporated by using a dummy variable that distinguishes the party type in power (LIBERAL for a positive surprise, 1- LIBERAL negative). ${ }^{15}$ Finally, our measure of surprise is modified to account for times when parliament was controlled by a minority government and hence for time periods when political behavior might well be anomalous. ${ }^{16}$ This effect is independent of party affiliation and is tested for directly through the use of the dummy variable, MINORITY. Thus using its inverse, 1-MINORITY, to indicate years with a more usual electoral outcome, the composite variable representing SURPRISE is defined as:

$$
\text { SURPRISE }=(1-\text { MINORITY })\{(1-\text { SEATS }) * \text { LIBERAL }-(1-\text { SEATS }) *(1-\text { LIBERAL })\} .
$$

13. Such arguments abstract from any effects that might arise from government redistribution from lower spending to higher spending groups.

14. Because the data is annual and most elections take place mid-year, it is not clear that the hypothesized boost to aggregate demand will arise in the previous rather than the current year (i.e., in the January - August period for a September election). Hence all equations were rerun with ELECTIONYEAR. This typically resulted in only small differences. See, however, footnote 20 below.

15. We do not test whether the size of the surprise is viewed as biased against the incumbent governing party. See Heckelman (2002) who argues that the Canadian data (1965-1996) is more consistent with symmetry across parties.

16. Kontopolous and Perotti (1999) and Persson, Roland and Tabellini (2004), for example, use a common-pooling argument to motivate higher than normal spending for coalition governments. Subsequent results confirm the wisdom of treaty minority governments as a distinct case. Using Beck and Campbell to define minority government, minority governments existed in Canada in the following periods: 1872-73, 1921-25, 1957, 1962-67, 1972-73, and 1979. Using the Canadian Parliamentary Guide, minorities existed in 1872-73, 1921-29, 1957, 1962-67, 1972-73, and 1979. 
The prediction of rational partisan theory is that the coefficient on SURPRISE will be positive.

The duration hypothesis of rational partisan political theory is tested through the sign of the coefficient of the composite variable

$$
\text { DURATION }=\{(\text { LIBERAL*ELAPSE })-(1-\text { LIBERAL }) * \text { ELAPSE }\},
$$

where ELAPSE is the time (in years) since the last election. Since the size of the stimulative (contractive) effect generated by the election of a Liberal (not Liberal) government is expected to dissipate as time in power elapses, the coefficient of DURATION should have a negative sign.

Finally, as discussed earlier, we control for more traditional economic reasons for variation in GROWTH and INFLATION in Canada by using USGROWTH and USINFLATION.

The resulting evidence for political cycles in Canada's annual macroeconomic data is presented in the OLS regression equations reported in Tables 2 and 3. Here each equation was rerun to allow for two possible measures of political outcomes in Canada, labeled as definitions A and B. Different interpretations of the size of the winning majority arise in Canada (especially in the first half of the 20th century) because closely associated, nominally independent candidates often ran unopposed by the winning political party and, once elected, tended to vote with the winning party. Hence judging whether or not they formed part of the winning coalition is problematic. ${ }^{17}$ In Tables 2 and 3 definition A refers to Beck and Campbell's (1977) judgement about which of the coalitions were durable, while definition $\mathrm{B}$ follows the Canadian Parliamentary Guide in using official party titles to measure the number of seats won by any officially designated political party. For both definitions, the first column represents our findings for the entire 1870-2000 time period, while the second represents the 1921-2000 sub-period over which data are somewhat easier to collect. We also note that the equations were also run over the 1945 to 2000 time period with no appreciable change in results (not shown), indicating that there is no suggestion in either Table 2 or 3 that political cycles are more prevalent now than they were before the Second World War. In addition, the use of a dummy variable for the periods of fixed exchange rates in Canada - 1870-1914, 1926-1931, 1939-1951, 1960-1972 - did not improve the fit nor was itself significant. Nor were experiments with interacting periods of fixed exchange rates with different political variables.

[Tables 2 and 3 here]

17. For example, in the election of 1872 where the Conservative party was elected with a minority of 99 Conservatives out of 200 seats as determined by the Canadian Parliamentary guide, Beck considers the outcome as a Conservative majority of 99 plus three Independent Conservatives plus one independent for 103 out of 200 seats. 
Table 2

The Effect of Political Variables on the Growth Rate in Canada: 1870 - 2000 (Newey-West HAC t-statistics in brackets).

\begin{tabular}{|c|c|c|c|c|}
\hline Dependent Variable & $\begin{array}{c}\text { GROWTH } \\
\text { of RGNP } \\
1873-2000\end{array}$ & $\begin{array}{c}\text { GROWTH } \\
\text { of RGNP } \\
1921-2000\end{array}$ & $\begin{array}{c}\text { GROWTH } \\
\text { of RGNP } \\
1873-2000\end{array}$ & $\begin{array}{c}\text { GROWTH } \\
\text { of RGNP } \\
1921-2000\end{array}$ \\
\hline Constant & $\begin{array}{l}1.08^{*} \\
(2.63)\end{array}$ & $\begin{array}{c}1.37 * \\
(3.26)\end{array}$ & $\begin{array}{l}1.07^{*} \\
(2.59)\end{array}$ & $\begin{array}{l}1.44 * \\
(3.39)\end{array}$ \\
\hline ELECTION YEAR(-1) & $\begin{array}{l}-0.006 \\
(0.009)\end{array}$ & $\begin{array}{c}0.080 \\
(0.139)\end{array}$ & $\begin{array}{c}0.050 \\
(0.010)\end{array}$ & $\begin{array}{c}0.212 \\
(0.374)\end{array}$ \\
\hline SURPRISE (definition A) & $\begin{array}{c}3.89 * \\
(3.82)\end{array}$ & $\begin{array}{l}3.22 * * \\
(2.39)\end{array}$ & & \\
\hline SURPRISE (definition B) & & & $\begin{array}{c}3.35^{*} \\
(3.58)\end{array}$ & $\begin{array}{l}2.33 * * * \\
(1.71)\end{array}$ \\
\hline MINORITY (definition A) & $\begin{array}{l}2.41 * * \\
(2.16)\end{array}$ & $\begin{array}{l}1.26^{* * * *} \\
(1.76)\end{array}$ & & \\
\hline MINORITY (definition B) & & & $\begin{array}{l}1.77 * * \\
(2.01)\end{array}$ & $\begin{array}{c}0.659 \\
(0.927)\end{array}$ \\
\hline DURATION & $\begin{array}{l}-0.267 \\
(1.33)\end{array}$ & $\begin{array}{l}-0.177 \\
(0.857)\end{array}$ & $\begin{array}{l}-0.182 \\
(0.927)\end{array}$ & $\begin{array}{l}-0.056 \\
(0.271)\end{array}$ \\
\hline USGROWTH & $\begin{array}{l}0.319^{*} \\
(6.99)\end{array}$ & $\begin{array}{l}0.340^{*} \\
(7.09)\end{array}$ & $\begin{array}{l}0.326^{*} \\
(6.56)\end{array}$ & $\begin{array}{l}0.350^{*} \\
(6.67)\end{array}$ \\
\hline USGROWTH(-1) & $\begin{array}{l}0.143^{*} \\
(3.27)\end{array}$ & $\begin{array}{l}0.123 * * * \\
(1.82)\end{array}$ & $\begin{array}{l}0.144^{*} \\
(3.24)\end{array}$ & $\begin{array}{l}0.123 * * * \\
(1.80)\end{array}$ \\
\hline USGROWTH(-2) & $\begin{array}{l}0.079 * * \\
(2.29)\end{array}$ & $\begin{array}{l}0.069 * * * \\
(1.70)\end{array}$ & $\begin{array}{l}0.083^{* *} \\
(2.34)\end{array}$ & $\begin{array}{l}0.073 * * * \\
(1.71)\end{array}$ \\
\hline $\begin{array}{l}\text { Statistics: } \\
\text { No. of Observations } \\
\text { Adj. R2 } \\
\text { D.W. } \\
\text { Akaike info criterion } \\
\text { Wald Prob: } \\
{[c(2)=c(3)=c(4)=c(5)=0]}\end{array}$ & $\begin{array}{l}128 \\
0.490 \\
2.25 \\
5.49 \\
.0003 *\end{array}$ & $\begin{array}{l}80 \\
0.630 \\
2.39 \\
5.13 \\
0.05^{* *}\end{array}$ & $\begin{array}{l}128 \\
0.477 \\
2.26 \\
5.52 \\
.0002 *\end{array}$ & $\begin{array}{c} \\
\quad 80 \\
0.621 \\
2.31 \\
5.16 \\
.156\end{array}$ \\
\hline
\end{tabular}

Notes: $*(* *)(* * *)$ significantly different from zero at $1 \%(5 \%)(10 \%)$.

SURPRISE $=\{1-$ MINORITY $\}\{(1-$ SEATS $) *$ LIBERAL $-(1-$ SEATS $) *(1-$ LIBERAL $)\}$.

DURATION $=\{($ LIBERAL*ELAPSE $)-(1-$ LIBERAL $) * E L A P S E ~\}$.

Definition A - Fraction of Seats won by the governing party and minority status as determined by Beck (1968): 1870-1944; Campbell (1977): 1945 - 1978; Canadian Parliamentary Guide (2002): 1979-2000.

Definition B - Fraction of Seats won by the governing party and minority status as determined by the Canadian Parliamentary Guide (2002): 1870-2000.

Note on the dating of elections: Elections occurring between January 1 and July 30 are considered applicable to the current calendar year; otherwise they are considered to be in the following year. (There was one election in July in 1930). 
Table 3

The Effect of Political Variables on the Inflation Rate in Canada: 1870 - 2000

(Newey-West HAC t-statistics in brackets)

\begin{tabular}{|c|c|c|c|c|}
\hline Dependent Variable & $\begin{array}{c}\text { Inflation Rate } \\
1872 \text { - } 2000\end{array}$ & $\begin{array}{c}\text { Inflation Rate } \\
\text { 1921-2000 }\end{array}$ & $\begin{array}{c}\text { Inflation Rate } \\
1872 \text { - } 2000\end{array}$ & $\begin{array}{c}\text { Inflation Rate } \\
\text { 1921-2000 }\end{array}$ \\
\hline Constant & $\begin{array}{l}0.543^{* * *} \\
(1.92)\end{array}$ & $\begin{array}{c}0.320 \\
(0.873)\end{array}$ & $\begin{array}{l}0.574 * * * \\
(1.99)\end{array}$ & $\begin{array}{c}0.375 \\
(1.06)\end{array}$ \\
\hline ELECTION YEAR(-1) & $\begin{array}{l}-0.307 \\
(0.742)\end{array}$ & $\begin{array}{c}0.222 \\
(0.583)\end{array}$ & $\begin{array}{l}-0.278 \\
(0.664)\end{array}$ & $\begin{array}{c}0.279 \\
(0.539)\end{array}$ \\
\hline SURPRISE (definition A) & $\begin{array}{l}2.34 * * \\
(2.08)\end{array}$ & $\begin{array}{l}1.75 \\
(1.52)\end{array}$ & & \\
\hline SURPRISE (definition B) & & & $\begin{array}{l}2.12 * * * \\
(1.90)\end{array}$ & $\begin{array}{c}1.42 \\
(1.27)\end{array}$ \\
\hline MINORITY (definition A) & $\begin{array}{c}0.876 \\
(0.974)\end{array}$ & $\begin{array}{l}-0.318 \\
(0.404)\end{array}$ & & \\
\hline MINORITY (definition B) & & & $\begin{array}{c}0.641 \\
(0.760)\end{array}$ & $\begin{array}{c}0.138 \\
(0.236)\end{array}$ \\
\hline DURATION & $\begin{array}{l}-0.274 \\
(1.26) \\
\end{array}$ & $\begin{array}{l}-0.116 \\
(0.649) \\
\end{array}$ & $\begin{array}{l}-0.234 \\
(1.10) \\
\end{array}$ & $\begin{array}{l}-0.062 \\
(0.368) \\
\end{array}$ \\
\hline USINFLATION & $\begin{array}{l}0.779 * \\
(11.94)\end{array}$ & $\begin{array}{l}0.790 * \\
(9.13)\end{array}$ & $\begin{array}{l}0.800^{*} \\
(11.48)\end{array}$ & $\begin{array}{l}0.803^{*} \\
(12.30)\end{array}$ \\
\hline USINFLATION(-1) & $\begin{array}{l}0.089 * * * \\
(1.79)\end{array}$ & $\begin{array}{c}0.078 \\
(1.34)\end{array}$ & $\begin{array}{c}0.066 \\
(1.21)\end{array}$ & $\begin{array}{c}0.063 \\
(1.03)\end{array}$ \\
\hline $\begin{array}{l}\text { Statistics: } \\
\text { No. of Obs } \\
\text { Adj. R2 } \\
\text { D.W. } \\
\text { Akaike Info criterion } \\
\text { WALD Prob. : } \\
{[c(2)=c(3)=c(4)=c(5)=0]}\end{array}$ & $\begin{array}{c}129 \\
0.732 \\
1.77 \\
4.67 \\
.174\end{array}$ & $\begin{array}{l}80 \\
0.779 \\
1.00 \\
4.36 \\
.383\end{array}$ & $\begin{array}{c}129 \\
0.729 \\
1.77 \\
4.68 \\
.208\end{array}$ & $\begin{array}{l}80 \\
0.776 \\
1.01 \\
4.37 \\
.647\end{array}$ \\
\hline
\end{tabular}

Notes: $*(* *)(* * *)$ significantly different from zero at $1 \%(5 \%)(10 \%)$.

For definitions, see Table 2. 
The results in Table 2 illustrate that despite the importance of economic factors in explaining the growth rate of Canadian output, as reflected in the significance of USGROWTH and its lags, the set of political variables do assist in explaining real growth. A Wald test rejects the hypothesis that the political variables as a group are jointly insignificant (at five percent or better) in three of the four cases, and SURPRISE is significant in all formulations (although more weakly so in the shorter time period). The two definitions of the size of the winning coalition and minority government produce roughly similar findings. In relative terms, however, the use of the Definition A measure of the size of the winning coalition produces coefficient estimates that are typically larger and more significant than does definition B.

Table 3, on the other hand, indicates that the political variables reflecting opportunism and partisanship have much less success in explaining the rate of inflation. The control variable for U.S. economic influence, USINFLATION, is highly significant and responsible for virtually all of the equation's overall explanatory power and, even though each political coefficient has its expected sign, only two of the political coefficients are marginally significant while the set of political variables as a group are inevitably insignificant. ${ }^{18}$

Overall, then, Canada's macroeconomic data are consistent with the hypothesis of a political cycle in annual real growth over the 1870 to 2000 time period, but give only very limited support to the hypothesis that the inflation rate exhibits a political cycle. ${ }^{19}$

We turn next to the question of which political hypotheses are consistent with cycles in output. First, the hypothesis that opportunistic pre-election spending results in a significantly positive effect on output growth is not supported by the data. ${ }^{20}$ Even though all four ELECTIONYEAR(-1) coefficients have their expected positive sign, all are insignificantly different from zero. In this sense, the data is more consistent with the non-significance implied by rational opportunistic theory, according to which any predictable pre-election behavior would be anticipated by the public so that its effect on behavior and output would be negligible.

Second, the data also suggest that periods of minority government, independent of party affiliation, are associated with real income growth and hence result in output effects that are anomalous with respect to "normal" election outcomes. In those elections, the surprise hypothesis predicted by rational partisan theory is broadly consistent with the data. Table 2 shows that the coefficient on the composite variable, SURPRISE, is positive in all equations and is significantly different from zero at five percent in three of the four equations (and at ten percent in the remaining one). Narrow LIBERAL victories are associated with larger increases in the output growth, while narrow Conservative victories correspond to periods with larger fall offs in the rate of output growth. Lastly, the political tenure hypothesis - that the effect of a partisan victory wears off through time - is suggested but not confirmed by the data. In three of the equations the predicted negative sign appears, but in all cases the coefficients are insignificantly different from zero. In summary, whether or not the data reject the hypothesis that political variables produce cycles in the inflation rate, our results are clearly consistent with the

18. Further evidence confirming this aspect of the results can be found in Winer (1986b).

19. Use of a dummy variable for the periods of fixed exchange rates in Canada - 1870-1914, 1926-1931, 1939-1951, 1960-1972 - did not improve the fit nor was itself significant. This is consistent with Winer (1986a) who found weak evidence for political cycles only in the higher frequency (quarterly) monetary data of the post 1972 period of exchange rate flexibility.

20. The use of the election year, rather than the year prior to the election, did produce a significantly positive coefficient in the inflation equations for 1921-2000 and hence did give some support to traditional opportunism. However, this improvement did not spill over into producing similarly better results for the other three hypotheses. 
hypothesis that there is a political cycle in aggregate real growth.

To assess the importance as opposed to the significance of the surprise effect, we ask what would be the predicted effect on the growth rate of a relative surprising Liberal (Conservative) election victory? Using as an example the narrow Liberal victory of 1926 (registering a surprise value of 0.480), we take the difference between that surprise and mean SURPRISE $(0.480-0.063=0.417)$ and then multiply the result by the coefficient estimate in column (1) of Table 2 . The calculation indicates that real growth would have been 1.62 percentage points higher than the 3.69 mean growth rate over the entire period. ${ }^{21}$ That is, our results suggest that the surprise Liberal victory in 1926 added roughly forty percent to the average annual growth rate over the period studied, a large number. On the same basis, the relatively surprising conservative victory in 1980 (a -0.479 surprise) produced a growth rate that was 1.62 percentage points lower than average. In either direction, the results indicate that a close election could affect the expected growth rate by well over a third.

The relative strength of the relationship between political events and real output growth (rather than inflation) suggests that the search for a transmission mechanism in public choices might well begin with fiscal rather than monetary policy. For this reason we proceed to examine in detail whether opportunism or partisanship play a role in explaining non-interest spending by Canada's central government. If we find at least some of these variables to be significant, we can then ask whether observed changes in these factors are consistent with the observed cyclical effects on real growth. Both the presence of a transmission mechanism and the consistent use of that mechanism are needed to support the joint hypothesis of a political cause for observed political cycles in macroeconomic aggregates.

\section{Methodology for the Study of the Role of Politics in the Evolution of Government Size}

The transmission of partisan and political opportunism through government size requires that corresponding political factors help to explain the evolution of public expenditure. We begin our investigation of this possible transmission mechanism by implementing the convergence hypothesis that government size depends only on variables that reflect underlying endowments, tastes and technology. ${ }^{22}$

It is important to emphasize that under the convergence hypothesis politics do matter, though not as implied by the usual partisan or opportunistic theories. Under convergence, political competition works by forcing governing parties to provide, over the long run, the level of spending demanded by the community, regardless of the particular state or timing of the political system concerning who is in power or the point in the electoral cycle. Because political competition is necessary for convergence, the degree of political competition should matter when implementing the convergence model. For this reason we test for its separate effect on convergence.

Our measure of the degree of political competition is the size of the wining majority in each election, SEATS. This is often used in the literature (see, for example, Levitt and Poterba 1999, Remmer and Wibbels 2000, and Besley, Persson and Sturm 2005) and assumes that ex post outcomes reflect the ex ante degree of party competition. ${ }^{23}$ The coefficient on SEATS, which is inversely related to the degree

21. Other elections with similar sized 'surprises', as defined here, were the 1976 and 1981 Liberal victories.

22. Previous work on growth of government in Canada is sparse, but includes notable early work by Bird (1970) as well as more recent contributions by Kneebone and McKenzie (1999), where the issue is one of several concerns, and with Canada as part of a panel, Dudley and Witt (2004).

23. It should be noted that SEATS is also used in the construction of SURPRISE, so that the issue of correlation between these variables arises. This proves not to be a problem: the two variables are almost orthogonal. The simple correlation between the two is -0.07 over the entire sample period 1870-2000 and -.06 over the period 1921-2000. 
of competition, provides a test of the hypothesis that more competition drives government size to converge on the size indicated by the tastes and preferences of the community. Since the absence of competition provides more scope for rent dissipation and for satisfying special interests through otherwise unwanted increases in real government size, we expect that the coefficient on SEATS to be positive if the degree of political competition matters in the convergence process. More generally, competition among parties has often been argued to result in government size conforming more closely to the wishes of the community (see Stigler 1972 and Becker 1983) so that any significant non-zero coefficient on SEATS would indicate the importance of competition in the evolution of the public policy process.

Figure 2 presents the dependent variable for our implementation of the convergence hypothesis. Here central government size is measured by total federal non-interest expenditure net of intergovernmental grants as a fraction of GNP (GSIZE). By netting out Equalization payments and other grants to the provinces (labeled GRANTS) from federal expenditures, we control for changes in federal spending that arise from federal-provincial bargaining. The difference this makes to our measure of federal government size is shown as the smaller of the two lines in Figure 2 below. In proportional terms, intergovernmental grants were most important in the period from the great depression until WWII and in the period following 1950 .

Figure 2

Central Government Size Relative to G N P, Canada 1870-2000

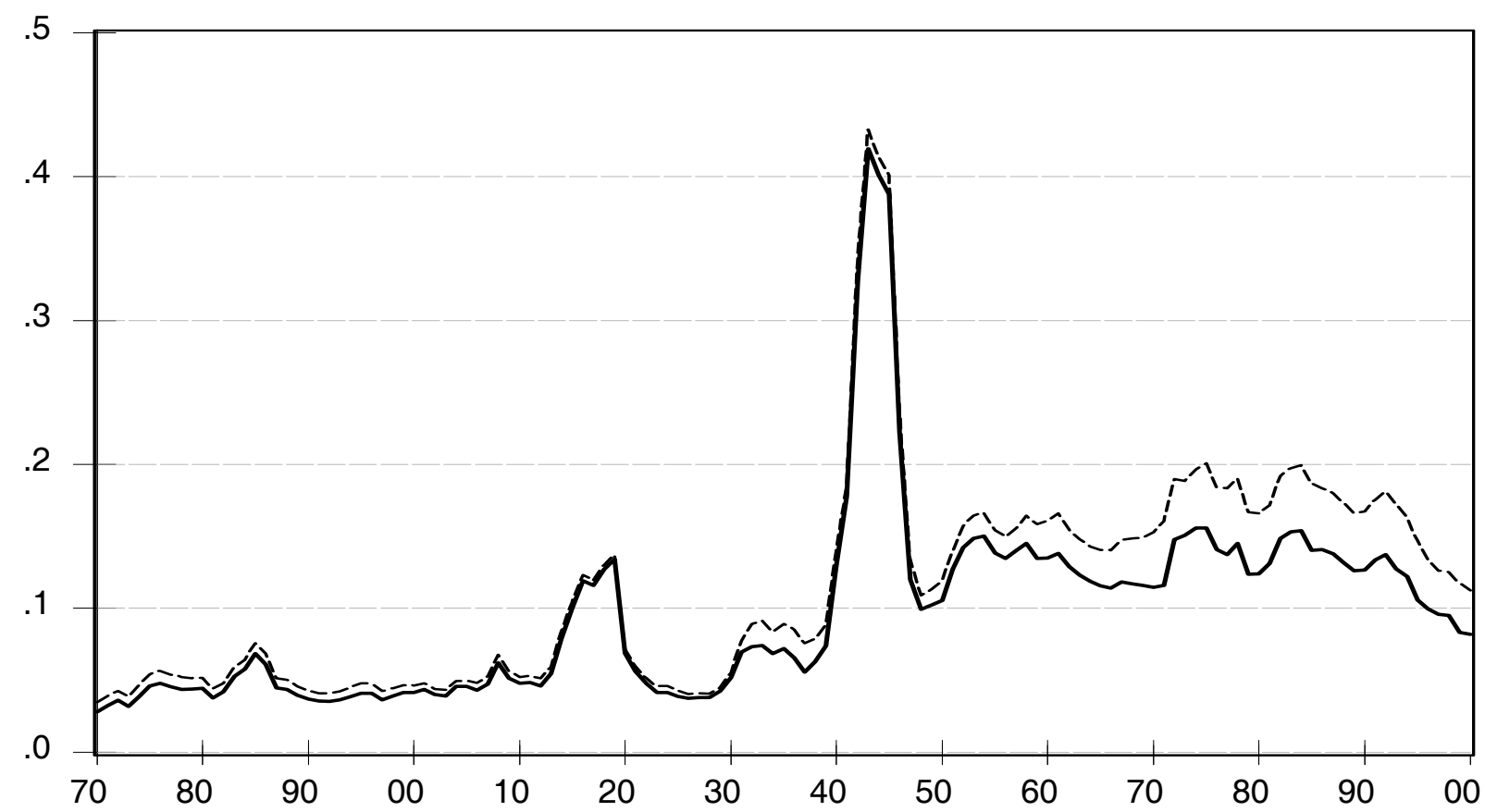

Federal Government Noninterest Expenditure Net of Grants/GNP Federal Government $\mathrm{N}$ oninterest Expenditure/G N P 
As Figure 2 illustrates, Canada's central government has grown in size more or less constantly over the entire 1870 - 2000 time period. Only since 1992 has there been some sign that this upward trend may be ending. What is perhaps most striking is the dramatic effect of the two world wars. In WWII, for example, the federal government grew from less than ten percent of GNP in 1939 to almost fifty percent by 1944, and then reversed most but not all of that gain by 1949. Figure 2 also suggests the existence of a displacement effect (Peacock and Wiseman 1961); that is, that the country adjusted to the experience of temporary large scale spending increase during WWII by acquiescing permanently in the expansion of government size. To allow for such a displacement in public expenditures, we include a dummy variable for the post WWII time period (WWIIAftermath) in the constant term of the cointegrating relationship used to describe the long run evolution of the public sector. In addition we use dummy variables to control for temporary breaks in expenditure arising during the two world wars. ${ }^{24}$ Finally, the history of public expenditure represented in Figure 2 shows an increase variance after the second world war as well as a shift in its mean. To allow for this rise in variance, we use the logarithm of government size (and other variables) in empirical work. The log of GSIZE (denoted LNGSIZE in Table 1a) has a standard deviation that is roughly constant across our two subperiods - 0.336 over 1870 - 1939 and 0.328 from 1939 to $2001 .^{25}$

To construct a long run model of LNGSIZE under the convergence hypothesis, we require a set of variables that both span the long time period covered (1870-2000) and reflect the deeper structure of the Canadian economy. The variables we use are standard in the literature on growth of government and have been widely relied upon in modeling various democratic states. ${ }^{26}$ The starting point is almost always Wagner's Law, the hypothesis that the size and scope of government increases more than in proportion as society grows in scale and complexity. This is interpreted as implying an elasticity of real per capita income (RYPC) with respect to size that is positive.

Wagner's Law is then enhanced by a set of hypotheses that suggest that the fraction of the population in agriculture (AGRIC) and the fraction of younger people (YOUNG) proxy changes in the structure of the economy and/or the strength of interest groups: as AGRIC declines and urbanization increases and as YOUNG declines and the percentage of older citizens grows, we should expect greater demands for government services. ${ }^{27}$ To capture other structural features that may promote more (or less) government involvement, we use immigration rates (IMRATIO) and the openness of the economy through its reliance on foreign trade (OPEN). ${ }^{28}$ All of these variables are used on log form, as indicated in the tables by the addition of the prefix LN to the variable names.

24. See Legrenzi (2004) for cross country evidence on the displacement effect and a recent test for Italy.

25. Any remaining heteroscedasticity in the error term (of LNGSIZE equations) is accounted for by using Newey-West HAC standard errors. Note in addition that GSIZE and many of the other explanatory variables (IMRATIO, AGRIC, YOUNG, and OPEN) are all confined to lie between zero and one. Hence transforming these variables into logarithms (adopting the prefix LN) avoids restrictions on the domain of the error terms in our estimating equations.

26. See, for example, Kau and Rubin (1981), Borcherding (1985), Mueller (1989), Ferris and West (1996) and Borcherding, Ferris and Garzoni (2004).

27. The use of these variables and not their complement - the degree of urbanization and the percent of population that is older than 65 years, is dictated by the availability of data for the entire time period we study.

28. Immigration played a major role in Canadian history, especially before WWI and in the decade following WWII. The use of OPEN follows Cameron (1978), Rodrik (1998) and others. One hypothesis is that more openness leads to more government as a form of insurance against external shocks. A competing view is that openness restrains government growth by imposing balance of payments and other external constraints. We shall see that this later view is more likely to apply in the Canadian case. One should also note that population is often used to test for scale economies in government size. Often scale economies are not found (see, Borcherding, Ferris and Garzoni, 2004) and, in Canada, the population time series is of a different order of integration than the other variables, i.e., I(2). For this reason, population size was not used as part of the convergence model. Finally, we note that in preliminary work the share of transfers in total federal spending (LNGRANT_SHARE) was used as an additional explanatory variable. Although consistently negative in its effect on size (and significantly so), its presence was never consistent with cointegration. 
Descriptive statistics for the log of these variables are presented in Table 1a where it is noted that LNGSIZE and the entire set of explanatory variables for the long run economic model of public sector size are nonstationary in levels but stationary in first differences or I(1) ${ }^{29}$ The political factors used to test for nonconvergence are introduced in the next section. Since these economic structural variables are nonstationary in their levels, any regression using these variables to explain LNGSIZE could be spurious. Nevertheless, if the residuals of the estimated equation in levels are stationary, we can interpret the result as evidence of a long run equilibrium relationship linking these variables with government size (Engle and Granger, 1987). Given that a stationary long run relationship can be found, we can then add SEATS (a stationary variable) to the long run model as our independent measure of the degree of political competition. $^{30}$

The residuals from this estimated relationship are used as the error term in an error correction model of short run adjustment about the long run equilibrium. The cointegrating equation and this error correction model together implement the convergence hypothesis, in which tastes and technology along with the degree of political competition explain both the longer run and shorter run adjustments of government size. ${ }^{31}$ It then follows that if the addition of a set of overtly political variables in this framework results in an expanded relationship that is cointegrated, we can conclude that political variables associated with opportunism and/or partisanship do indeed form part of the explanation of government size. This would be convincing evidence of "nonconvergence".

\section{Cointegration and the Long Run Model of Government Size}

The convergence or base case model of government size (without the degree of political competition SEATS) is presented in the first two columns of Table 4. The estimated relationship allows for several shifts in the intercept of the cointegrating equation: first, during both world wars; second, in the time period following the end of WWII; and, finally, for periods when the exchange rate was fixed versus flexible. The use of the exchange regime is suggested by the well-known Mundell-Fleming class of open economy models where fiscal policy is a more potent policy instrument in a fixed rather than flexible exchange rate regime.

The first column in the table presents the base case cointegrating equation over the entire 1870-2000 time period and the second column repeats the same OLS estimation over the shorter period from 1921 for which, in some cases, the data are better. In both cases, the ADF test statistic on the equation residuals falls well inside the modified MacKinnon (1996) critical value for a cointegrating equation with six explanatory I(1) variables. ${ }^{32}$

[Table 4 here]

29. All unit root tests used four lags.

30. Note that once cointegration among the set of $\mathrm{I}(1)$ variables has been established, an $\mathrm{I}(0)$ variable can be added without producing inconsistency in the degrees of integration.

31. We recall here footnote 4 concerning our reliance on the Engel-Granger approach. Results using the Johansen approach to cointegration are also provided below.

32. As far as we are aware, there are no tables of critical values for cointegration relationships with structural breaks occurring at known break points. Gregory and Hanson (1996), for example, give approximate critical values for the ADF test of a Engle-Granger type cointegration equation with a single structural break arising at an unknown points. Hence despite the relative high (absolute) values on the ADF statistics of our cointegration residuals, the implied significance may be overstated. 
Table 4

Long Run Model of Government Size

Canadian Federal Government Expenditures as a Fraction of GDP: 1870 - 2000

(Absolute values of t-statistics in brackets) \#

\begin{tabular}{|c|c|c|c|c|}
\hline Dependent Variable & $\begin{array}{c}(1) \\
\text { LNGSIZE: } \\
\text { Base Case } \\
1870 \text { - } 2000\end{array}$ & $\begin{array}{c}(2) \\
\text { LNGSIZE } \\
\text { Base Case } \\
1921 \text { - } 2000\end{array}$ & $\begin{array}{c}(3) \\
\text { LNGSIZE: } \\
\text { Political } \\
1870 \text { - } 2000\end{array}$ & $\begin{array}{c}(4) \\
\text { LNGSIZE: } \\
\text { Political } \\
1921 \text { - } 2000\end{array}$ \\
\hline Constant & $\begin{array}{l}-5.25 \\
(3.59)\end{array}$ & $\begin{array}{l}-5.06 \\
(1.59)\end{array}$ & $\begin{array}{l}-6.54 \\
(3.07)\end{array}$ & $\begin{array}{l}-5.02 \\
(1.56)\end{array}$ \\
\hline LNRYPC & $\begin{array}{l}0.254 \\
(2.51)\end{array}$ & $\begin{array}{c}0.290 \\
(0.873)\end{array}$ & $\begin{array}{c}0.300 \\
(1.83)\end{array}$ & $\begin{array}{c}0.283 \\
(0.828)\end{array}$ \\
\hline LNAGRIC & $\begin{array}{c}0.121 \\
(1.66)\end{array}$ & $\begin{array}{c}0.147 \\
(0.811)\end{array}$ & $\begin{array}{l}0.097 \\
(1.07)\end{array}$ & $\begin{array}{c}0.141 \\
(0.742)\end{array}$ \\
\hline LNYOUNG & $\begin{array}{l}-0.103 \\
(0.402)\end{array}$ & $\begin{array}{l}-0.435 \\
(1.50)\end{array}$ & $\begin{array}{c}0.060 \\
(0.179)\end{array}$ & $\begin{array}{l}-0.431 \\
(1.46)\end{array}$ \\
\hline LNIMRATIO & $\begin{array}{l}-0.060 \\
(2.78)\end{array}$ & $\begin{array}{l}-0.148 \\
(5.05)\end{array}$ & $\begin{array}{l}-0.061 \\
(1.96)\end{array}$ & $\begin{array}{l}-0.147 \\
(4.76)\end{array}$ \\
\hline LNOPEN & $\begin{array}{l}-0.544 \\
(4.04)\end{array}$ & $\begin{array}{l}-0.810 \\
(4.84)\end{array}$ & $\begin{array}{l}-0.505 \\
(2.34)\end{array}$ & $\begin{array}{l}-0.807 \\
(4.74)\end{array}$ \\
\hline WWI & $\begin{array}{r}0.809 \\
(9.08)\end{array}$ & & $\begin{array}{c}0.779 \\
(6.29)\end{array}$ & \\
\hline WWII & $\begin{array}{c}1.85 \\
(16.34)\end{array}$ & $\begin{array}{c}1.70 \\
(12.50)\end{array}$ & $\begin{array}{c}1.77 \\
(8.70)\end{array}$ & $\begin{array}{c}1.70 \\
(12.41)\end{array}$ \\
\hline WWII Aftermath & $\begin{array}{r}0.809 \\
(9.74)\end{array}$ & $\begin{array}{r}0.845 \\
(8.94)\end{array}$ & $\begin{array}{c}0.748 \\
(10.44)\end{array}$ & $\begin{array}{r}0.844 \\
(8.79)\end{array}$ \\
\hline $\begin{array}{l}\text { FIXED EXCHANGE } \\
\text { RATEt }\end{array}$ & $\begin{array}{l}-0.214 \\
(4.66)\end{array}$ & $\begin{array}{l}-0.147 \\
(3.19)\end{array}$ & $\begin{array}{l}-0.191 \\
(3.57)\end{array}$ & $\begin{array}{l}-0.145 \\
(3.04)\end{array}$ \\
\hline SEATS & & & $\begin{array}{c}0.519 \\
(1.91)\end{array}$ & $\begin{array}{l}-0.021 \\
(0.110)\end{array}$ \\
\hline $\begin{array}{l}\text { Statistics: } \\
\text { No. of Observations } \\
\text { Adj. R2 } \\
\text { D.W. } \\
\text { Akaike info criterion } \\
\text { A.D.F. statistic on residuals } \\
\text { MacKinnon critical values: } \\
\text { (at } 1 \% \text { for } 6 \text { vars }=-5.12 \text { ) } \\
\text { (at } 1 \% \text { for } 7 \text { vars }=-5.44 \text { ) }\end{array}$ & $\begin{array}{c}131 \\
0.920 \\
0.888 \\
-0.627\end{array}$ & $\begin{array}{c}80 \\
0.920 \\
1.38 \\
-0.943\end{array}$ & $\begin{array}{c}131 \\
0.925 \\
0.947 \\
-0.674\end{array}$ & $\begin{array}{c}80 \\
0.919 \\
1.38 \\
-0.918\end{array}$ \\
\hline
\end{tabular}

Notes:\# The t-statistics in these regressions are inconsistent because of correlations arising among the random components of the I(1) variables and hence are unreliable for use as significance tests. See accompanying Table 5 for Saikkonen's adjustment method.

t The periods when exchange rates were fixed in Canada are: 1870-1914, 1926-1931, 1939-1951, and 1960-1972. 
A look across the first two rows for each time period indicates a remarkable degree of consistency in the sign and size of the coefficient estimates. ${ }^{33}$ As expected, government size appears to be significantly larger in the two world wars and, consistent with the Peacock Wiseman displacement hypothesis, appears to be significantly larger in WWII's aftermath. Neither LNAGRIC nor LNYOUNG appear significant and LNOPEN has a negative coefficient, to which we return later. Perhaps somewhat surprisingly, our results suggest that government size was consistently larger in periods when the exchange rate was flexible rather than fixed. ${ }^{34}$

Caution is required in judging the significance of these estimates, however, and we postpone further discussion of them for now. That is, while the equations in Table 4 are consistent with the hypothesis of a long-run equilibrium relationship among the variables (with known structural shifts in the intercept), it is likely that the innovations among the I(1) variables in the equation are correlated. This implies that the standard errors of the coefficients will be inconsistent. To discuss the significance of the individual coefficients, we follow Saikkonen (1991) and adjust the equations and their standard errors. [This is done in Table 5 below]. Nevertheless, because the OLS coefficient estimates are themselves super consistent, the equation as a whole can be utilized as a reliable indicator of whether cointegration exists. And on this basis, equations (1) and (2) do indicate that a cointegrating relationship can be found among the key I(1) economic variables suggested by the literature on growth of government. With cointegration among these variables, the I(0) variable SEATS, measuring the degree of political competition, can be added to the equation.

The next step is to determine whether any of the opportunistic and partisanship political variables form part of the cointegrating relationship. Because the political variables used to test for cycles in growth rates are all $\mathrm{I}(0)$, it seems unlikely that any of them would contribute to an explanation of long run government size modelled through a collection of mainly I(1) economic variables. ${ }^{35}$ Hence we expect that if political variables are significant in explaining government size, evidence of the relationship will more likely be revealed by the error correction equation than by the long run model.

Nonetheless, we consider how opportunistic and partisanship political factors affect size in the long run. To do so we must recognize that by changing from a test of the effect of politics on output to a test of the effect of politics on government size, a change in perspective is required. Unlike the test of the rational partisanship hypothesis, where surprise spending is important for an effect on output, surprise is not needed for evidence of a partisanship effect on government size. For government size to be the mechanism by which output is affected through political surprise, the change in size must simply be present in order for the effect on output to have been possible. In this sense, the test for the effect of political factors on government size is more straightforward than is the test for politics on growth, a point that to our knowledge has not been recognized in the literature.

It then follows that all fiscal opportunism theories, whether traditional or rational, require only that government size increase in the period leading into an election. ${ }^{36}$ Thus for their presence to be

33. The exception is the coefficient of LNYOUNG whose large standard error implies that all are insignificantly different from zero. See the Saikkonen results in Table 5.

34. This seems surprising only in the sense that Mundell-Fleming reasoning suggests that fiscal policy should be more effective in altering aggregate demand under fixed exchange rates. However if variations in size are more effective, then larger changes in size are not needed to counter effective demand failures. Moreover, a flexible rate may to some extent free the government from the balance of payments constraint on policy choices generally.

35 . Note as above that the $I(0)$ political variables can be incorporated into the regression equation because of the $I(0)$ property of the cointegrating vector.

36. The theories of asymmetric information that suggest that opportunism cannot be effective in the long run also imply that such "unnecessary" spending will be embodied in the equilibrium. That is, if incumbent parties do not spend (as expected) before an election, then aggregate demand will be affected adversely with resulting party losses. Asymmetric information then traps both political parties and the electorate into an equilibrium that is second best (compared to a 
confirmed, the coefficient of ELECTIONYEAR(-1) must be positive. ${ }^{37}$ Similarly, partisan theories require LIBERAL victories to result in greater spending (compared to the alternative). Moreover, should any partisan effect arise, any diminution (or expansion) of that partisan effect over the tenure of governments would depend on the type of party elected. This we test for through the composite DURATION variable introduced previously.

Our earlier test for surprise allowed for the possibility that government behavior might be anomalous in periods of minority government and this we continue. Minority governments may affect spending and output positively in the long run because of common pool problems in budgetary negotiations (Kontopolous and Perotti 1999, and Persson, Roland and Tabellini 2004), resulting in a coefficient on MINORITY that will be positive with respect to government size. Finally, our measure of political competition, SEATS, is included to test for its role in the convergence model. Here a positive coefficient would indicate that a reduction in the degree of competition allows the party with more "market power" to spend more at lower political cost, independent of partisan affiliation. ${ }^{38}$

Columns (3) and (4) in Table 4 present the final stage of our iterative search for cointegration among the enhanced set of economic and political variables. ${ }^{39}$ This search procedure started by adding all political variables discussed immediately above (ELECTIONYEAR-1, LIBERAL, DURATION, MINORITY) to the base case equations of columns (1) and (2), as well as the measure of the degree of political competition SEATS. The inability to find evidence of cointegration among this set then led us to eliminate the least significant variable and retest. We continued in this manner until all the political variables but SEATS were eliminated and the models in columns (3) and (4) were isolated.

The most interesting aspect of the results is what is missing from the table. The results indicate that the political variables representing the timing of electoral events and/or the binary switching of power between partisan opposites do not enter the cointegrating equation. Only the measure of political competition remains. In part such results might have been expected on the basis of the differences in the order of integration in the two sets of variables as we noted above. Nevertheless, our measure of political competition does explain part of the variance in the cointegrating equation indicating that political competition does play a role in convergence to economic 'fundamentals'.

A sense of the importance of the degree of competition political competition can be seen in the simulations presented in Figure 3. In that figure we simulate the difference it would have made for long run government size if political competition was uniform and intense. To do this we first generate the predicted value of long run government size from the equation estimates in column (3) of Table 4, shown as the dashed line on the figure. We then simulate long run size under the hypothesis that the degree of political competition (SEATS) remained the same at 0.5 over the whole time period. This is represented by the solid line on the following Figure 3. While the use of 0.5 to represent the outcome that would arise under intense or perfect political competition is somewhat arbitrary, the result does show that greater competition would have eliminated some of the more dramatic periods of government growth,

world where such inefficiencies could be eliminated costlessly).

37. Note that because the instrument must be affected ahead of the expected policy result, changes in government spending must precede the desired change in output. This implies ELECTIONYEAR(-1) and perhaps even ELECTIONYEAR(-2) would be more appropriate that ELECTIONYEAR itself. Experimentation with all these forms produced no appreciable difference.

38. Note that in a parliamentary system it will be the percentage of seats won rather than the percentage of the popular vote that will form the better measure of political competition. Nevertheless, we did rerun all our work using a measure of popular support for the governing party (not presented but available on request) and, as might be expected, found broadly similar (but less significant) findings.

39. In the tests we follow the Beck/Campbell/Parliamentary Guide (definition A) measure of the of winning majorities and whether there was a minority government. The tests were rerun for competing definition B, based on the Canadian Parliamentary Guide exclusively throughout, with no appreciable change in results. 
especially during the very large (in terms of SEATS) Conservative governments of John Diefenbaker (1957 - 63) and Brian Mulroney (1984 - 93).

Figure 3

The Effect of Imperfect Political Competition on the Size of Government 1950 - 2000

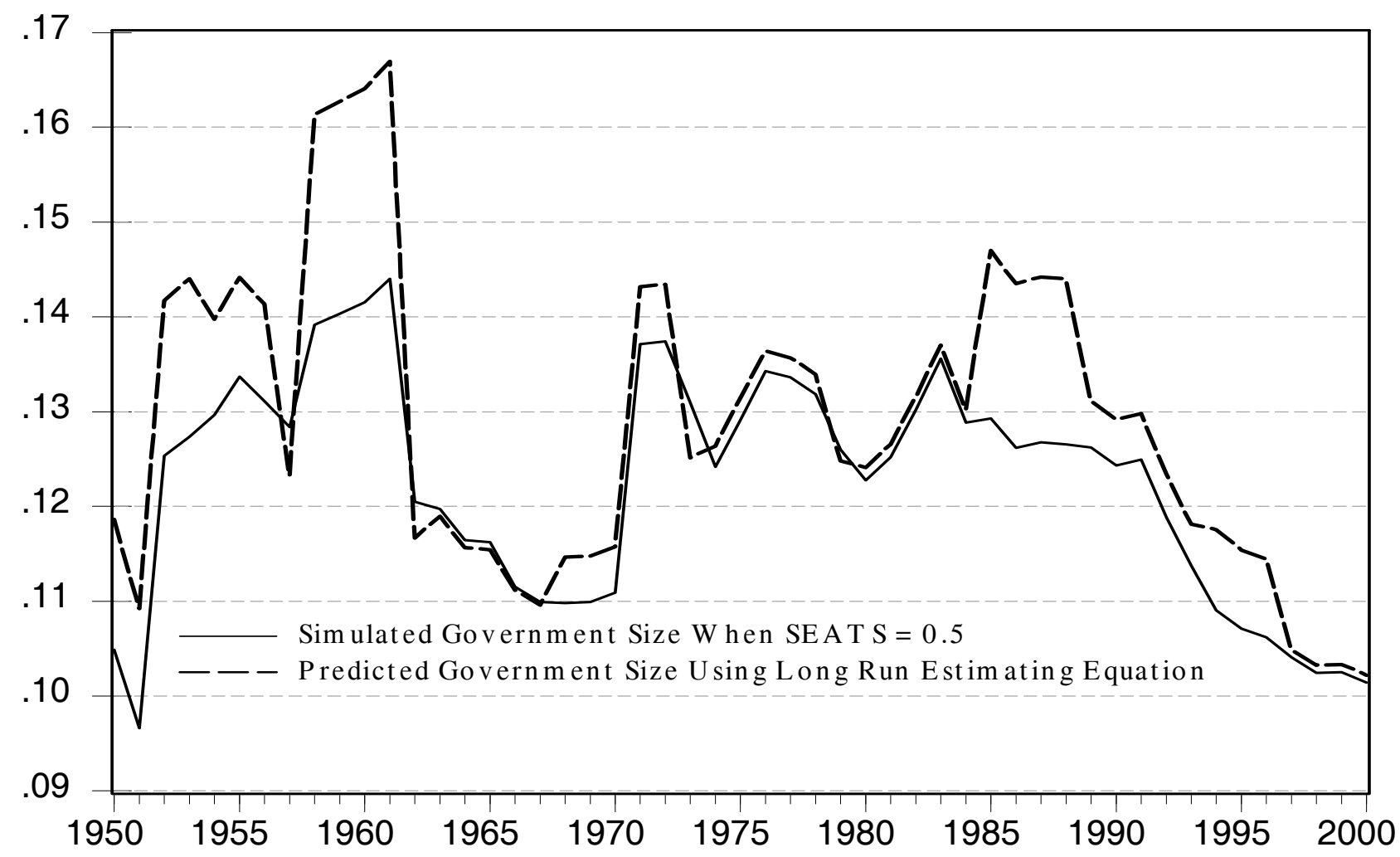

Governments in less competitive periods: 1948-1957 - Liberal (St. Laurent); 1957-1963 - Conservative (Diefenbaker); 1984-1993 - Conservative (Mulroney); 1993-2003 - Liberal (Chretien)

4.1 Further results concerning SEATS and the degree of political competition

Since the role of political competition is not usually investigated in empirical studies of government size, it seems wise to investigate the robustness of our results in this respect. In the first place, it might be argued that the alternative indicator of the degree of competition - (0.5 - SEATS) - more directly reflects the idea that any departure from a 'balanced' situation indicates a lessening of competition. But this reformulation adds only a constant to the estimated coefficient and does not alter the results in Table 4.

Second, since SEATS is based on the results of elections it seems wise to consider the possibility that it is endogenous in the present context. In doing so, however, one should note that SEATS is the size of the winning majority independent of party type. Hence while one might hypothesize that a larger sized government would increase the size of the incumbent's majority or the winning majority of the more 
liberal party, we have no particular reason to believe that causality would run from government size to larger electoral majorities independent of incumbency and/or party type. Moreover, from a cointegration perspective, even if SEATS is endogenous the estimation in Table 4 remains consistent, although in that case it is no longer clear that causality runs only from the degree of competition to government size.

Nonetheless, we proceed with a Hausman test for the endogeneity of SEATS, using U.S. growth and U.S. inflation and lagged SEATS as instruments. This test indicates that SEATS is exogenous, although the hypothesis of endogeneity just fails at the 10 percent level ${ }^{40}$ Continuing to allow for possible endogeneity, we consider what happens when one replaces SEATS with its lag, that is, with the share of seats in the legislature won by the governing party in the previous election, which is predetermined. Here the results in Table 4 again remain essentially unaffected, with the coefficient on SEATS lagged in column (3) of the table now becoming equal to 0.72 with a t- statistic of $1.93 .{ }^{41}$

A cointegration analysis using the Johansen methodology in which the potential endogeneity of SEATS is allowed for by including it in the cointegrating relation along with economic fundamentals is provided in section 6 below.

\subsection{Saikkonen Adjustments in the long run convergence model}

The primary role of the preceding section has been to find the long-run cointegrating relationship on which we can base our error correction model of short run adjustment. In moving forward, we take the residuals from equations (1) and (3) as the error correction terms to be used in the convergent and nonconvergent models of short run adjustment.

Before we turn to this error-correction formulation, we complete our long run analysis by presenting in Table 5 the Saikkonen (1991) adjustments for serial correlation among the error terms of the set of I(1) variables in the cointegrating equation. Such correlations make the coefficient standard errors inconsistent and overstate the size of the t-statistics that arise under OLS estimation. As shown in Table 5 , even though this proved to be the case, the individual hypotheses generally retain both their degree of significance and algebraic sign after the Saikkonen adjustment was performed. Hence our results suggest that Wagner's Law holds for Canada in the long run, that structural variables such as the rate of immigration and the degree of openness do assist in explaining government size over the longer run. ${ }^{42}$

\section{[Table 5 here]}

Note in particular that while openness continues to matter, it does so robustly in a way that is opposite to that suggested by Rodrik (1998) and Cameron (1978). In Canada, greater trade openness is associated with a smaller rather than larger government sector, perhaps because openness erodes the power of special interests and makes more difficult the collection of "higher" tax revenues. These effects may dominate any increased need for social assistance to deal with greater insecurity of more open borders. This result is consistent with the negative effect of fixed exchange rates on LNGSIZE in Table 5 if we interpret the latter result as stemming from the tighter balance of payments constraints of a fixed rate regime.

40. The complete set of exogenous variables used in the first stage of the test includes all of the variables in Table 4 except for LNRYPC, and includes USGROWTH and its lag and USINFLATION and its lag, as well as SEATS lagged. Adding another lag of the last three variables leads to the clear rejection of endogeneity at 10 percent.

41. This result is based on the use of Newey-West HAC standard errors.

42. LNYOUNG was consistently the weakest of our set of potential explanatory variables, never reaching significance at $10 \%$. LNAGRIC is significantly positive in column 2 while we expected it to have a negative coefficient. 
Table 5

Saikkonen Supplement to Table 4

Canadian Federal Government Expenditures as a Fraction of GDP: 1870 - 2000

(Absolute values of Saikkonen adjusted t-statistics in brackets) ${ }^{\#}$

\begin{tabular}{|c|c|c|}
\hline Dependent Variable & $\begin{array}{c}(\mathbf{1}) \\
\text { LNGSIZE: Base Case } \\
\text { from Table 4, Col. (1) } \\
1872 \text { - } 1999\end{array}$ & $\begin{array}{c}\text { (2) } \\
\text { LNGSIZE: Politics Case } \\
\text { from Table 4, Col. (3) } \\
1872 \text { - } 1999\end{array}$ \\
\hline Constant & $\begin{array}{l}-7.72 * \\
(3.31)\end{array}$ & $\begin{array}{l}-9.62 * \\
(5.55)\end{array}$ \\
\hline LNRYPC & $\begin{array}{c}0.394 * \\
(2.81)\end{array}$ & $\begin{array}{c}0.501 * \\
(4.83)\end{array}$ \\
\hline LNAGRIC & $\begin{array}{l}0.187 \\
(1.39)\end{array}$ & $\begin{array}{c}0.220 * * \\
(2.30)\end{array}$ \\
\hline LNYOUNG & $\begin{array}{c}0.309 \\
(0.695)\end{array}$ & $\begin{array}{l}0.486 \\
(1.52)\end{array}$ \\
\hline LNIMRATIO & $\begin{array}{c}-0.081 * * \\
(2.40)\end{array}$ & $\begin{array}{c}-0.067^{*} \\
(2.77)\end{array}$ \\
\hline LNOPEN & $\begin{array}{c}-0.350 * * * \\
(1.63)\end{array}$ & $\begin{array}{c}-0.339 * * \\
(2.21)\end{array}$ \\
\hline WWI & $\begin{array}{c}0.634 * \\
(4.73)\end{array}$ & $\begin{array}{c}0.627 * \\
(6.38)\end{array}$ \\
\hline WWII & $\begin{array}{c}1.642 * \\
(9.66)\end{array}$ & $\begin{array}{c}1.65 * \\
(13.64)\end{array}$ \\
\hline WWIIAftermath & $\begin{array}{c}0.821 * \\
(4.90)\end{array}$ & $\begin{array}{c}0.786^{*} \\
(6.56)\end{array}$ \\
\hline FIXED EXCHANGE RATES & $\begin{array}{c}-0.192 * \\
(3.21)\end{array}$ & $\begin{array}{c}-0.168 * \\
(3.91)\end{array}$ \\
\hline SEATS & & $\begin{array}{c}0.781 * \\
(3.92)\end{array}$ \\
\hline $\begin{array}{l}\text { Statistics: } \\
\text { No. of Observations } \\
\text { Adj. } \text { R }^{2} \\
\text { D.W. } \\
\text { Akaike info criterion } \\
\text { Saikkonen adjustment factor }\end{array}$ & $\begin{array}{c}128 \\
0.940 \\
0.860 \\
-0.802 \\
0.728\end{array}$ & $\begin{array}{c}128 \\
0.948 \\
1.100 \\
-0.945 \\
0.949\end{array}$ \\
\hline
\end{tabular}

Notes: $*(* *)[* * *]$ significantly different from zero at $1(5)[10] \%$.

\# Saikkonen's (1991) estimator adjusts for inconsistency in the standard errors of the I(1) variables in the cointegrating equation by including the contemporaneous, lagged and led values of the first differences of both left and right hand side variables (with the exception of the dummy variables WWI, WWII, WWIIAftermath, and the fixed exchange rate dummy). Only the coefficients of the level terms are relevant and so presented. In addition, the standard errors and t-statistics had to be adjusted for the presence of correlation among the innovations of the I(1) variables by a factor formed by the ratio of two standard errors a) the standard error of the augmented equation divided by b) the "long run standard error". The latter is calculated as the square root of the variance plus two times the weighted sum of the significant autocovariances among the 
Finally, and of particular interest, SEATS retains its significance and size after the Saikkonen adjustment, indicating the importance of political competition in the longer run.

\section{Error Correction Models of Government Size}

While one might be surprised if the timing and/or partisan nature of political events mattered for the long run size of government, it would be much less surprising to find that political factors do matter in relation to short run cyclical variation about that long run size. Indeed, the power of partisan and opportunistic political theories is their implicit reliance on the strategic use of transitory spending to influence individual behavior and aggregate output over shorter horizons.

To test for the presence of political factors in the adjustment process we use the error correction models presented in Tables $6 \mathrm{a}, 6 \mathrm{~b}$ and $6 \mathrm{c} .{ }^{43}$ Table $6 \mathrm{a}$ presents only contemporaneous first differences in formulating the error correction model in the Engle-Granger tradition. Table $6 \mathrm{~b}$ expands that model to capture more of the intertemporal adjustment process through the use of three lagged values of the first differences. Finally, Table $6 \mathrm{c}$ reports the results of a Johansen-type error correction analysis when SEATS is included in the cointegrating equations. All of these variations lead to the same general conclusion - that political competition is the only political variable that matters in addition to economic fundamentals. In particular, the political factors used in Tables 2 and 3 do not play a significant role.

Columns (1) and (2) of Table 6a present the two error correction models that correspond to our base case, economic convergence hypothesis presented in Table 4. To explain the choice of variables appearing in the table, we follow the methodology of incorporating the current value first differences of all the potential economic and public choice variables together with dummy variables allowing for potential breaks at the time intervals associated with breaks in the long run. In addition, we included a dummy variable for periods when the exchange rate was fixed (the exchange regime may influence the choice of fiscal policy instrument in the short run as well as in the ling run), and we also include changes in the scale of federal transfer payments to other levels of government as a share of non-interest federal spending net of grants, D(LNGRANT_SHARE). In keeping with our concern with the role of political competition, the latter variable allows for a measure of intergovernmental competition. That is, short run changes in the size of federal transfers to provincial and local governments could well speed up or hold back competing federal programs and so influence the ability of the federal government to exercise spending discretion in relation to the cycle.

\section{[Table 6a here]}

With this enhanced set of variables, the error correction equations of columns (1) and (2) were estimated. The resulting relationships work well, explaining between sixty and seventy percent of the short run variation in government size over the 1870-2000 and 1921- 2000 time periods. ${ }^{44}$ In addition, the coefficient estimates are broadly similar across the two equations and, in each of the equations, the error correction term was negative as expected (for convergence to the long run to occur) and significantly different from zero at one percent. The estimated size of the error correction coefficient implies that deviations from long run size are corrected over five years.

43. Once again the rerunning of the equations using only the Canadian Parliamentary guide definitions of MINORITY and SEATS led to no significant change in our findings.

44. When the equations were rerun over the 1945 to 2000 time period, the error correction term became insignificant, suggesting that short run adjustment was distinctly different in the later time period. For an interpretation of what was happening in the post WWII time period, see Ferris and Winer, 2003. 
Table 6a

Error Correction Model of Government Size

The Change in Canadian Federal Government Expenditures as a Fraction of GDP: 1870 - 2000 ( Absolute value of t-statistics in brackets)

\begin{tabular}{|c|c|c|c|c|}
\hline & $\begin{array}{c}(1) \\
\text { Base Case } \\
1871 \text { - } 2000\end{array}$ & $\begin{array}{c}(2) \\
\text { Equations } \\
1921 \text { - } 2000\end{array}$ & $\begin{array}{c}\text { (3) } \\
\text { Political } \\
1871-2000\end{array}$ & $\begin{array}{c}(4) \\
\text { Variables } \\
1921 \text { - } 2000\end{array}$ \\
\hline Dependent Variable & D(LNGSIZE) & D(LNGSIZE) & D(LNGSIZE) & D(LNGSIZE) \\
\hline Error Correction term & $\begin{array}{l}-0.170^{*} \\
(3.01)\end{array}$ & $\begin{array}{l}-0.299^{*} \\
(3.43)\end{array}$ & $\begin{array}{l}-0.219^{*} \\
(3.77)\end{array}$ & $\begin{array}{l}-0.305^{*} \\
(3.59)\end{array}$ \\
\hline D(LNRYPC) & $\begin{array}{l}-0.792 * \\
(3.86)\end{array}$ & $\begin{array}{l}-0.702 * * \\
(2.29)\end{array}$ & $\begin{array}{l}-0.843^{*} \\
(4.23)\end{array}$ & $\begin{array}{l}-0.739 * * \\
(2.48)\end{array}$ \\
\hline D(LNAGRIC) & $\begin{array}{l}-0.447 \\
(1.53)\end{array}$ & $\begin{array}{l}-0.271 \\
(0.804)\end{array}$ & $\begin{array}{l}-0.396 \\
(1.39)\end{array}$ & $\begin{array}{l}-0.209 \\
(0.634)\end{array}$ \\
\hline D(LNYOUNG) & $\begin{array}{l}-0.616 \\
(0.588)\end{array}$ & $\begin{array}{l}-0.560 \\
(0.524)\end{array}$ & $\begin{array}{l}-2.10 * * * \\
(1.87)\end{array}$ & $\begin{array}{l}-1.70 \\
(1.46)\end{array}$ \\
\hline D(LNIMRATIO) & $\begin{array}{l}-0.103^{*} \\
(4.19)\end{array}$ & $\begin{array}{l}-0.156^{*} \\
(4.74)\end{array}$ & $\begin{array}{l}-0.094^{*} \\
(3.86)\end{array}$ & $\begin{array}{l}-0.135^{*} \\
(4.01)\end{array}$ \\
\hline D(LNOPEN) & $\begin{array}{l}-0.195 \\
(1.15)\end{array}$ & $\begin{array}{l}-0.385^{* * * *} \\
(1.81)\end{array}$ & $\begin{array}{l}-0.139 \\
(0.844)\end{array}$ & $\begin{array}{l}-0.381 \text { *** } \\
(1.84)\end{array}$ \\
\hline Constant & $\begin{array}{l}-0.001 \\
(0.074)\end{array}$ & $\begin{array}{l}-0.009 \\
(0.447)\end{array}$ & $\begin{array}{l}-0.198^{*} \\
(2.67)\end{array}$ & $\begin{array}{l}-0.165^{* * *} \\
(2.01)\end{array}$ \\
\hline WWI & $\begin{array}{c}0.058 \\
(1.17)\end{array}$ & & $\begin{array}{c}0.073 \\
(1.51)\end{array}$ & \\
\hline WWIAfter & $\begin{array}{l}-0.179^{*} \\
(2.62)\end{array}$ & & $\begin{array}{l}-0.190^{*} \\
(2.86)\end{array}$ & \\
\hline WWII & $\begin{array}{l}0.178^{*} \\
(3.88)\end{array}$ & $\begin{array}{l}0.189^{*} \\
(3.77)\end{array}$ & $\begin{array}{l}0.146^{*} \\
(3.22)\end{array}$ & $\begin{array}{l}0.150^{*} \\
(2.89)\end{array}$ \\
\hline WWIIAfter & $\begin{array}{l}-0.255^{*} \\
(4.49)\end{array}$ & $\begin{array}{l}-0.257^{*} \\
(4.29)\end{array}$ & $\begin{array}{l}-2.09 \\
(3.73)\end{array}$ & $\begin{array}{l}-0.251^{*} \\
(4.30)\end{array}$ \\
\hline FIXED EXCHANGE RATES & $\begin{array}{c}0.028 \\
(1.44)\end{array}$ & $\begin{array}{c}0.028 \\
(0.998)\end{array}$ & $\begin{array}{l}0.033 * * * \\
(1.75)\end{array}$ & $\begin{array}{c}0.044 \\
(1.55)\end{array}$ \\
\hline D(LNGRANT_SHARE) & $\begin{array}{l}-0.423^{*} \\
(7.65)\end{array}$ & $\begin{array}{l}-0.367^{*} \\
(5.84)\end{array}$ & $\begin{array}{l}-0.394^{*} \\
(7.26)\end{array}$ & $\begin{array}{l}-0.348^{*} \\
(5.63)\end{array}$ \\
\hline SEATS & & & $\begin{array}{l}0.311^{*} \\
(2.72)\end{array}$ & $\begin{array}{l}0.278 * * \\
(2.18)\end{array}$ \\
\hline $\begin{array}{l}\text { Statistics: } \\
\text { No. of Observations } \\
\text { Adj. R2 } \\
\text { D.W. } \\
\text { Serial Corr. LM test NR2 (3 } \\
\text { lags) } \\
\text { Akaike info criterion }\end{array}$ & $\begin{array}{c}130 \\
0.633 \\
1.82 \\
8.62 * * \\
-1.70\end{array}$ & $\begin{array}{l}79 \\
0.650 \\
1.84 \\
2.89 \\
-1.69\end{array}$ & $\begin{array}{c}130 \\
0.656 \\
1.83 \\
4.61 \\
-1.76\end{array}$ & $\begin{array}{l}79 \\
0.668 \\
1.88 \\
0.816 \\
-1.73\end{array}$ \\
\hline
\end{tabular}

Notes: * $(* *)[* * *]$ significant at $1 \%(5 \%)(10 \%)$.

The error correction term used for each equation was the lagged residual from the corresponding column in Table 4.

Minority uses definition A. 
In the error correction model of Table 6a, the only time period dummy previously employed that becomes insignificant is the one for WWI. In addition, although changes in government size show no significant response to periods of fixed exchange rates, the estimated coefficient changes from negative (in the long run model of Tables 4 and 5 ) to positive, suggesting that government size was adjusted more often in response to transitory economic events in periods of fixed (rather than flexible) exchange rates. Anticipating our later results (as presented in columns (3) and (4)) of Table 6a), greater reliance on fiscal policy is indicated somewhat more strongly in the political version of the error correction model.

In terms of economic meaning, one of the most interesting features of the error correction model is that the coefficient estimate on the contemporaneous change in income is significantly negative in all equations and hence opposite in sign to the long run coefficient estimates found in Tables 4 and 5 . This provides strong evidence of a counter cyclical role for government size in the short run. Hence the data is consistent both with Keynesian counter cyclical fiscal policy in the short run and Wagner's Law over the long run. This illustrates how the co-presence of two hypotheses implying opposing relationships over different time horizons can easily be co-mingled in different tests that do not distinguish longer and shorter run effects. As might be expected with respect to our other hypotheses, structural features of the economy which matter most for the long run show up in varying degrees of importance in the short run.

Another feature of our error correction equations is that increases in the share of intergovernmental transfers (out of federal spending) are associated with declines in federal government size. Our guess is that these changes reflect the political strength of the federal government versus the provinces and so capture the negative effect of greater intergovernmental competition on federal government size. While our explanation for this effect is somewhat ad hoc, the results consistently suggest an effect that is both substantive and pervasive. It is significantly negative in every form of the test run for Table $6 \mathrm{a}$ and in subsequent estimations using different approaches.

The final step is to test for the significance of politics on short run variations in size by adding the set of political variables to the model, using the same general to specific methodology as before to test down to reveal significant political variables. The remaining two columns of Table 6a present these nonconvergence hypothesis results for the 1870 - 2000 and 1921 - 2000 time periods. As columns (3) and (4) indicate, all of our designated political variables have no effect on short run variations in government size. Neither the time period leading into an election (ELECTIONYEAR(-1)), the more liberal government, LIBERAL, periods of minority government, MINORITY nor the duration of partisan power (DURATION) have any consistent effect on short run variations in government size. None of the partisan or opportunistic political variables are significantly different from zero. ${ }^{45}$

However, the data does support the hypothesis that the size of the winning electoral majority, SEATS, matters for explaining short run variations in government size. Moreover, the significance of SEATS is independent of electoral timing, the partisan affiliation of the political party in power, whether or not we control for periods of minority government and the duration of the time in power. It follows that while we do find evidence that one dimension of politics matters for short run variations in government size, that variation is not consistent with either political business theory of the cycle. Rather, evidence that large majorities of both partisan types result in a temporarily larger sized government is consistent with the hypothesis that it is the lack of competition among political parties that results in the temporary "overexpansion" of government size relative to that desired by the community. As such the error correction model produces evidence consistent with political competition driving convergence in the short as well as the long run.

A feeling for the magnitude of the SEATS effect can be gained by estimating the predicted consequence

45. In the appendix we present an Extreme Bounds Analysis of SEATS by adding each the political variables individually and in combination to the equation of column (3) of Table 6a. In no case was a political variable other than SEATS significant. 
for the growth in government size of having an electoral victory of the size of John Diefenbaker's Progressive Conservative landslide victory in 1958. This is an outlier representing the most lopsided election victory in Canadian federal political history, with the Conservative party capturing of $78.5 \%$ of the seats in the House of Commons. Using our long period estimates, a victory of this scale would have been expected to lead to approximately a 5.7 percentage point higher rate of growth of (relative) government size. ${ }^{46}$ Given that the mean growth rate of federal government size over the entire period was slightly below one per cent per year, such a result would temporarily increase the annual growth rate of government size six times. Alternatively, one standard deviation increase in SEATS (of 8.6 percent) leads to an increase in the growth of GSIZE of about 2.7 percent. At the very least, these results indicate that the consequences of a lack of political competition can be substantive.

\subsection{Other formulations of the error correction model.}

Table $6 \mathrm{~b}$ presents a fuller formulation of the dynamic short run adjustment process in government size using three lagged first differences of the economic variables (although results are robust for lags between one and four). As with Table 6a, effective representation of the wars must allow for the rapid increase in spending during a war and for the subsequent rapid decrease thereafter. This involves the use of the dummy variables WWIAfter and WW2After. Just as in Table 6a, but with much less evidence of serial correlation in the model, the only political factor that remains significant in the short run is SEATS. Other results remain essentially unchanged. Once again, the role of political competition appears substantial. ${ }^{47}$

\section{[Table 6b here]}

Finally, we use Johansen methodology (Johansen 1991, 1995) to search for the number of cointegrating vectors and present the corresponding error correction model. This formulation allows for the possible endogeneity of SEATS in the long run by including it as part of the cointegrating relation. Placing SEATS third after LNGSIZE and LNRYPC in an ordered group of economic determinants that also include LNAGRIC, LNIMRATIO, LNYOUNG and LNOPEN, and without using any exogenous determinants except for a linear trend in the data and intercept in the cointegrating relation, the Trace statistic suggests there are 3 cointegrating relations at 5\%, while the Maximum Eigenvalue test suggests that there are 2 cointegrating vectors. (Omission of SEATS from the list of potential members of the cointegrating relations leads to the conclusion that there are two cointegrating vectors using either test.)

Including SEATS in the cointegrating group and assuming that there are three cointegrating relations results in the vector error correction models shown in Table $6 \mathrm{c}$ for our two time periods. Here the AIC criterion is used to determine the 5 lags that should be used for the longer period and the 4 lags for the shorter period. For convenience, most of the lagged first differences are omitted from the table and only the equations for LNGSIZE, LNRYPC and SEATS are recorded. In general the conclusions about the political variables remain unaffected by this form and the choice of other dynamic lag structures (from one to six). Given the economic factors, of all the political factors considered only SEATS matters in the short run adjustment process.

\section{[Table 6c here]}

The error correction terms in the table clearly indicate the consequences of the degree of competition for increases in government size across the short run adjustment process. The effects of government spending on SEATS, on the other hand, are more muted, judging again by the error correction terms as well as by impulse responses to a standard deviation shock.

46. The calculation is $(78.5-60.2)^{*} .311=5.7 \%$, where $60.2 \%$ is the percentage of seats held on average by the winning political party. The mean growth rate of GSIZE, federal non-interest spending net of grants, over the entire period from 1870 is $0.823 \%$.

47. The same calculations as in Table 6a indicate that a victory on the scale of the 1958 Conservative landslide would result in roughly the same increase in real growth (of 5.3\%) and that a one standard deviation increase in SEATS leads to a similar increase in the growth of GSIZE (of $2.5 \%$ ). 
Table 6b

Error Correction Model of Government Size Using 3 Lags

The Change in Canadian Federal Government Expenditures as a Fraction of GDP: 1870 - 2000

(Absolute values of t-statistics in brackets)

\begin{tabular}{|c|c|c|c|c|}
\hline & $\begin{array}{c}(1) \\
\text { Base Case } \\
1874-2000\end{array}$ & $\begin{array}{c}\text { (2) } \\
\text { Equations } \\
1922 \text { - 2000 } \\
\end{array}$ & $\begin{array}{c}\text { (3) } \\
\text { Political } \\
1874-2000\end{array}$ & $\begin{array}{l}\text { (4) } \\
\text { Variables } \\
1922 \text { - } 2000 \\
\end{array}$ \\
\hline Dependent Variable & D(LNGSIZE) & D(LNGSIZE) & D(LNGSIZE) & D(LNGSIZE) \\
\hline Error Correction term & $-0.107 * * *(1.710)$ & $-0.119(1.31)$ & $-0.156^{* *}(2.33)$ & $-0.206 * *(2.05)$ \\
\hline $\begin{array}{l}\text { D(LNRYPC) } \\
-\operatorname{lags~} 1 \text { - } 3\end{array}$ & $\begin{aligned}-0.754 * & (3.48) \\
0.261 & (1.00) \\
-0.027 & (0.113) \\
-0.349 & (1.58)\end{aligned}$ & $\begin{array}{c}-0.460(1.40) \\
0.193(0.498) \\
-0.167(0.462) \\
-0.289(0.850)\end{array}$ & $\begin{array}{c}-0.850 *(3.93) \\
0.151 \quad(0.583) \\
-0.054(0.225) \\
-0.358(1.65)\end{array}$ & $\begin{array}{c}-0.674 * *(2.01) \\
0.142(0.381) \\
-0.311 \quad(0.880) \\
-0.349(1.044)\end{array}$ \\
\hline $\begin{array}{l}\text { D(LNAGRIC) } \\
\text { - lags } 1 \text { - } 3\end{array}$ & $\begin{array}{c}-0.246(0.782) \\
-0.746 * *(2.25) \\
-0.241(0.727) \\
0.226(0.702)\end{array}$ & $\begin{array}{c}-0.222(0.624) \\
-0.723 * *(1.95) \\
-0.548(1.43) \\
0.254(0.672)\end{array}$ & $\begin{array}{c}-0.201 \quad(0.653) \\
-0.756 * *(2.33) \\
-0.214(0.658) \\
0.228(0.726)\end{array}$ & $\begin{array}{c}-0.114(0.328) \\
-0.618 * *(1.732) \\
-0.443(1.200) \\
0.316(0.865)\end{array}$ \\
\hline $\begin{array}{l}\text { D(LNYOUNG) } \\
\text { - lags 1-3 }\end{array}$ & $\begin{aligned}-1.568 & (0.442) \\
4.465 & (1.012) \\
-3.545 & (0.835) \\
-0.970 & (0.296)\end{aligned}$ & $\begin{array}{r}-1.617(0.398) \\
4.647(0.920) \\
-0.334(0.068) \\
-4.495(1.160)\end{array}$ & $\begin{aligned}-4.190 & (1.147) \\
4.148 & (0.962) \\
-3.319 & (0.799) \\
0.548 & (0.168)\end{aligned}$ & $\begin{aligned}-5.193 & (1.232) \\
4.514 & (0.927) \\
-0.605 & (0.128) \\
-1.622 & (0.420)\end{aligned}$ \\
\hline $\begin{array}{l}\text { D(LNIMRATIO) } \\
\text { - lags 1-3 }\end{array}$ & $\begin{array}{ll}-0.104 * & (3.77) \\
-0.019 & (0.621) \\
-0.010 & (0.332) \\
0.035 & (0.124)\end{array}$ & $\begin{array}{l}-0.161 *(4.20) \\
-0.023(0.537) \\
-0.086 *(2.25) \\
-0.007(0.177)\end{array}$ & $\begin{array}{cc}-0.090 * & (3.238) \\
-0.009 & (0.276) \\
0.0004 & (0.013) \\
0.039 & (1.397)\end{array}$ & $\begin{aligned}-0.135 * & (3.40) \\
0.011 & (0.257) \\
-0.042 & (0.977) \\
0.004 & (0.106)\end{aligned}$ \\
\hline $\begin{array}{l}\text { D(LNOPEN) } \\
\text { - lags 1-3 }\end{array}$ & $\begin{array}{c}-0.044(0.226) \\
-0.622 *(3.00) \\
0.026(0.126) \\
-0.078(0.426) \\
\end{array}$ & $\begin{array}{l}-0.323(1.19) \\
-0.293(1.053) \\
-0.273(1.05) \\
0.130(0.526) \\
\end{array}$ & $\begin{array}{c}-0.016(0.081) \\
-0.553 *(2.70) \\
0.022(0.110) \\
-0.114(0.636) \\
\end{array}$ & $\begin{array}{cc}-0.409 & (1.563) \\
-0.292 & (1.070) \\
-0.288 & (1.149) \\
0.021 & (0.086) \\
\end{array}$ \\
\hline Constant & $-0.021(0.892)$ & $-0.039(1.498)$ & $-0.190 * *(2.45)$ & $-0.195 * *(2.20)$ \\
\hline WWI & $0.112 * * *(1.86)$ & & $0.134 * *(2.25)$ & \\
\hline WWIAfter & $-0.184 * *(2.38)$ & & $-0.212 *(2.77)$ & \\
\hline WWII & $0.176 *(3.15)$ & $0.147 * *(2.34)$ & $0.172 *(3.16)$ & $0.168 *(2.66)$ \\
\hline WWIIAfter & $-0.283 *(3.71)$ & $-0.236 *(2.72)$ & $-0.250 *(3.37)$ & $-0.262 *(3.02)$ \\
\hline FIXED EXCHANGE RATES & $0.031(1.42)$ & $0.059(1.86)^{* * *}$ & $0.033(1.58)$ & $0.057 * * *(1.86)$ \\
\hline D(LNGRANT_SHARE) & $-0.426 *(7.13)$ & $-0.395 *(5.29)$ & $-0.412 *(7.02)$ & $-0.374 *(5.19)$ \\
\hline SEATS & & & $0.276 *(2.28)$ & $0.292 * *(1.99)$ \\
\hline $\begin{array}{l}\text { Statistics: } \\
\text { No. of Observations } \\
\text { Adj. R2 } \\
\text { D.W. } \\
\text { Serial Corr. LM test NR2 } \\
\text { (3 lags) } \\
\text { Akaike info criterion }\end{array}$ & $\begin{array}{c}127 \\
0.669 \\
1.97 \\
11.55^{*} \\
-1.69\end{array}$ & $\begin{array}{l}80 \\
0.655 \\
2.09 \\
3.26 \\
-1.57\end{array}$ & $\begin{array}{l}127 \\
0.683 \\
1.996 \\
25.52 * \\
-1.73\end{array}$ & $\begin{array}{l}79 \\
0.680 \\
2.24 \\
3.53 \\
-1.64\end{array}$ \\
\hline
\end{tabular}

Notes : $*(*)[* * *]$ significant at $1 \%(5 \%)(10 \%)$.

Lag lengths from 1 to 3 do not alter conclusions about role of political factors LIBERAL, MINORITY, DURATION and ELECTIONYEAR(-1). The error correction term used was the lagged residuals of column (j) of Table 4 for the corresponding column in this table 
Table 6c

Error Correction Model of Government Size Using the Johansen Approach (3) The Change in Canadian Federal Government Expenditures as a Fraction of GDP: 1870 - 2000 (Absolute values of t-statistics in brackets)

\begin{tabular}{|c|c|c|c|c|c|c|}
\hline & $\begin{array}{c}(1) \\
1876-2000 \\
\text { Using } 5 \text { lags } \\
\end{array}$ & & & $\begin{array}{c}(2) \\
1921-2000 \\
\text { Using } 4 \text { lags } \\
\end{array}$ & & \\
\hline Dependent Variable & D(LNGSIZE) & D(LNRYPC) & D(SEATS) & D(LNGSIZE) & D(LNRYPC) & D(SEATS) \\
\hline $\begin{array}{c}\text { Error Correction terms } \\
\text { LNGSIZE } \\
\text { LNRYPC } \\
\text { SEATS } \\
\end{array}$ & $\begin{array}{r}-0.401 *(4.33) \\
0.501 *(4.22) \\
1.07 * *(3.44) \\
\end{array}$ & $\begin{array}{r}-0.005(0.124) \\
0.034(0.591) \\
-0.058(0.375) \\
\end{array}$ & $\begin{array}{r}-0.002(0.022) \\
0.039(0.486) \\
-0.143(0.682) \\
\end{array}$ & $\begin{array}{l}-0.356 *(3.60) \\
1.46 *(3.42) \\
0.463(1.25) \\
\end{array}$ & $\begin{array}{l}0.002(0.061) \\
-0.483 *(2.90) \\
-0.29 * * *(2.04) \\
\end{array}$ & $\begin{array}{l}0.076(0.945) \\
-0.605(1.75) \\
-0.717 * *(2.40) \\
\end{array}$ \\
\hline $\begin{array}{l}\text { D(LNGSIZE) } \\
\text { lags } 1 \text { - } 2 \text { only }\end{array}$ & $\begin{array}{l}0.20 * * *(1.93) \\
0.285 *(2.94)\end{array}$ & $\begin{array}{r}-0.030(0.569) \\
0.008(0.176)\end{array}$ & $\begin{array}{l}0.077(1.09) \\
0.163 * *(2.51)\end{array}$ & $\begin{array}{l}0.355^{*}(2.87) \\
0.427 *(3.06)\end{array}$ & $\begin{array}{l}-0.070(1.44) \\
-0.043(0.782)\end{array}$ & $\begin{array}{l}0.079(0.793) \\
0.22 * * *(1.92)\end{array}$ \\
\hline $\begin{array}{l}\text { D(LNRYPC) } \\
\text { lags } 1 \text { - } 2 \text { only }\end{array}$ & $\begin{array}{l}-0.62 * * *(2.03) \\
-0.355(1.15)\end{array}$ & $\begin{array}{l}-0.097(0.647) \\
-0.091(0.603)\end{array}$ & $\begin{array}{r}-0.047(0.232) \\
0.047(0.603)\end{array}$ & $\begin{array}{l}-1.28 * *(2.63) \\
-1.13 * *(2.52)\end{array}$ & $\begin{array}{l}0.36 * * *(1.92) \\
0.532 *(2.73)\end{array}$ & $\begin{array}{l}0.314(0.858) \\
0.570(1.44)\end{array}$ \\
\hline $\begin{array}{l}\text { D(SEATS) } \\
\text { lags } 1 \text { - } 2 \text { only }\end{array}$ & $\begin{array}{l}-0.923 *(2.85) \\
-0.54 * *(2.12)\end{array}$ & $\begin{array}{r}0.100(0.625) \\
-0.058(0.463)\end{array}$ & $\begin{array}{l}-0.188(0.864) \\
-0.037(0.215)\end{array}$ & $\begin{array}{l}-0.302(1.02) \\
-0.219(0.857)\end{array}$ & $\begin{array}{l}0.296 * *(2.57) \\
0.18 * * *(1.83)\end{array}$ & $\begin{array}{l}0.198(0.830) \\
0.297(1.44)\end{array}$ \\
\hline $\begin{array}{l}\text { D(LNAGRIC) } \\
\text { lags } 1 \text { - } 2 \text { only }\end{array}$ & $\begin{array}{l}-0.459(1.15) \\
-0.489(1.26)\end{array}$ & $\begin{array}{c}-0.119(0.601) \\
0.205(1.07)\end{array}$ & $\begin{array}{r}0.158(0.586) \\
-0.140(0.536)\end{array}$ & $\begin{array}{l}-0.731(1.71) \\
-0.76^{* * *}(1.92)\end{array}$ & $\begin{array}{l}0.060(0.357) \\
0.453 *(2.93)\end{array}$ & $\begin{array}{c}0.288(0.832) \\
-0.234(0.728)\end{array}$ \\
\hline $\begin{array}{l}\text { D(LNYOUNG) } \\
\text { lags 1-2 only }\end{array}$ & $\begin{array}{r}-0.697(0.166) \\
0.128(0.023)\end{array}$ & $\begin{array}{l}-0.471(0.226) \\
-1.03(0.372)\end{array}$ & $\begin{array}{c}-0.480(0.170) \\
5.74(1.53)\end{array}$ & $\begin{array}{l}4.33(0.843) \\
3.38(0.626)\end{array}$ & $\begin{array}{l}-0.006(0.003) \\
-3.222(1.52)\end{array}$ & $\begin{array}{l}7.91 * * *(1.81) \\
-4.842(1.08)\end{array}$ \\
\hline $\begin{array}{l}\text { D(LNIMRATIO) } \\
\text { lags 1-2 only }\end{array}$ & $\begin{array}{l}0.047(1.28) \\
0.038(1.13)\end{array}$ & $\begin{array}{l}0.004(0.210) \\
0.012(0.698)\end{array}$ & $\begin{array}{l}0.012(0.463) \\
0.04 * * *(1.84)\end{array}$ & $\begin{array}{l}0.125 * *(2.27) \\
0.065(1.30)\end{array}$ & $\begin{array}{l}-0.003(0.144) \\
-0.006(0.292)\end{array}$ & $\begin{array}{l}0.029(0.653) \\
0.080 * *(1.97)\end{array}$ \\
\hline $\begin{array}{l}\text { D(LNOPEN) } \\
\text { lags 1-2 only }\end{array}$ & $\begin{array}{c}-0.49 * * *(1.96) \\
0.305(1.19)\end{array}$ & $\begin{array}{c}0.208(1.68) \\
-0.028(0.218)\end{array}$ & $\begin{array}{l}0.048(0.285) \\
0.33 * * *(1.89)\end{array}$ & $\begin{array}{c}0.007(0.021) \\
-0.083(0.294)\end{array}$ & $\begin{array}{l}-0.214(1.61) \\
-0.186(1.69)\end{array}$ & $\begin{array}{l}0.651(0.070) \\
0.042(0.183)\end{array}$ \\
\hline Constant & $-0.162 *(2.63)$ & $0.029(0.959)$ & $0.035(0.841)$ & $0.154(1.10)$ & $-0.127 * *(2.32)$ & $-0.170(1.50)$ \\
\hline WWI & $0.2703(2.95)$ & $-0.058(1.28)$ & $-0.078(1.25)$ & & & \\
\hline WWIAfter & $-0.037(0.382)$ & $-0.09 * * *(1.91)$ & $0.041(0.624)$ & & & \\
\hline WWII & $0.403 *(3.69)$ & $0.11 * * *(1.95)$ & $-0.030(0.404)$ & $0.175(1.26)$ & $0.185^{*}(3.40)$ & $0.061(0.544)$ \\
\hline WWIIAfter & $-0.214 * *(1.97)$ & $-0.066(1.23)$ & $0.105(1.44)$ & $-0.141(0.953)$ & $-0.098(1.71)$ & $-0.009(0.074)$ \\
\hline WWIIAfterMath & $0.323 *(3.03)$ & $0.011(0.220)$ & $-0.011(0.153)$ & $-0.099(0.596)$ & $0.208 *(3.21)$ & $0.26^{* * * *}(1.92)$ \\
\hline $\begin{array}{l}\text { FIXED EXCHANGE } \\
\text { RATES } \\
\end{array}$ & $-0.020(0.618)$ & $-0.0003(0.02)$ & $-0.021(0.963)$ & $-.079(1.65)$ & $0.016(0.861)$ & $-0.009(0.241)$ \\
\hline D(LNGRANT_SHARE) & $-0.285^{*}(3.45)$ & $-0.060(1.48)$ & $-0.026(1.48)$ & $-0.355 *(3.50)$ & $-0.08 * *(2.12)$ & $0.027(0.331)$ \\
\hline $\begin{array}{l}\text { Statistics: } \\
\text { No. of Observations } \\
\text { Adj. R2 } \\
\text { Akaike info criterion }\end{array}$ & $\begin{array}{c}125 \\
0.644 \\
-1.54 \\
\end{array}$ & $\begin{array}{r}125 \\
0.141 \\
-2.95 \\
\end{array}$ & $\begin{array}{c}125 \\
0.170 \\
-2.95 \\
\end{array}$ & $\begin{array}{c}80 \\
0.676 \\
-1.58 \\
\end{array}$ & $\begin{array}{c}80 \\
0.462 \\
-3.46 \\
\end{array}$ & $\begin{array}{c}80 \\
0.267 \\
-2.00 \\
\end{array}$ \\
\hline
\end{tabular}

Notes: $*(* *)[* * *]$ significant at $1 \%(5 \%)(10 \%)$.

Only the first two lags of the lagged first difference terms are shown in the table. 
Finally, as shown by the accumulated response to a one standard deviation in Figure 4, we note that the positive effect of SEATS on LNGSIZE is both larger and longer than the opposite effect of government size on SEATS. Somewhat more of an effect of LNGSIZE on SEATS arises in the results for estimation over the shorter time period from 1921.

Figure 4

Cumulative Responses to One Standard Deviation Shocks Based on the Error Correction Model in Table 6c

1876-2000

Accumulated Response to Generalized One S.D. Innovations
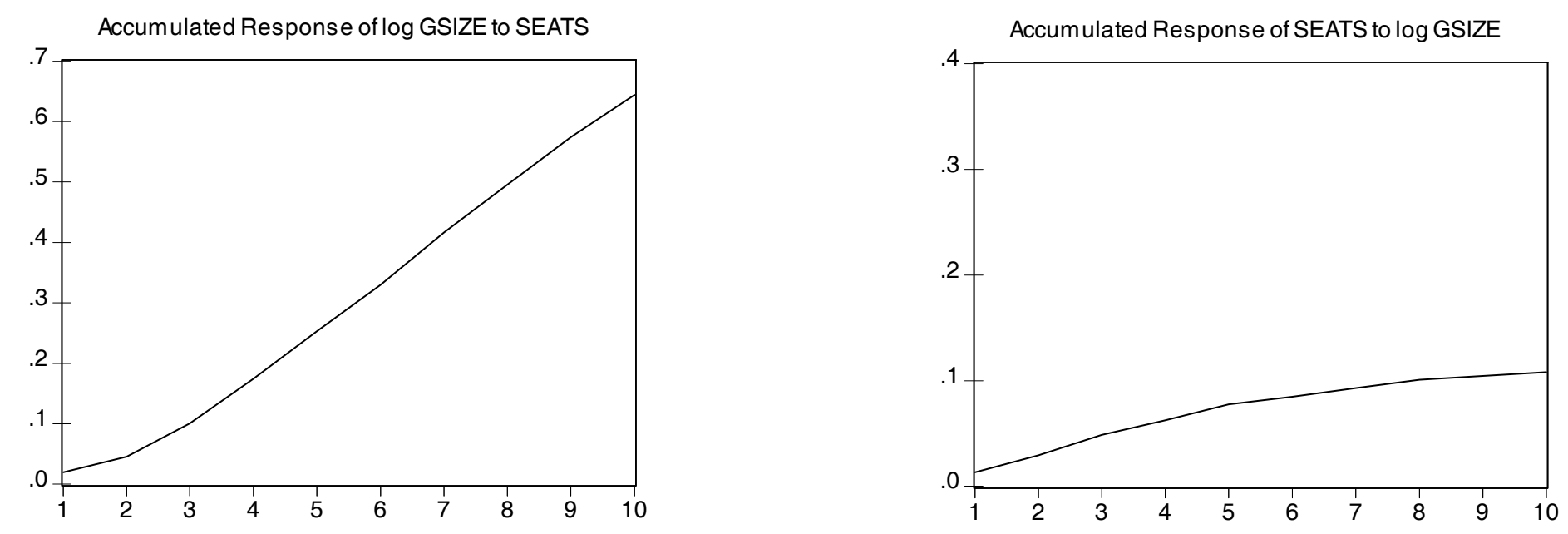

$1921-2000$

Accumulated Response to Generalized One S.D. Innovations
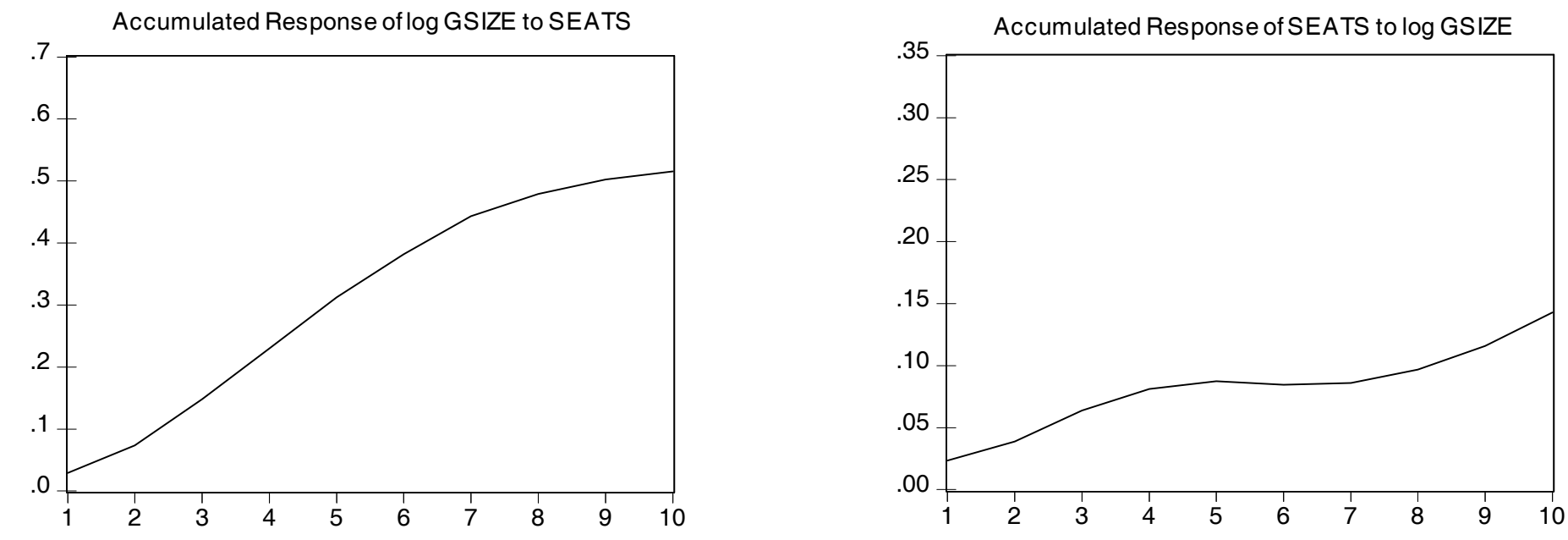


\section{Conclusion}

We have addressed the problem of how to assess the empirical importance of economic as opposed to political factors in the context of a search for a transmission mechanism lying behind an observed political business cycle in aggregate real growth. The specific problem in this context was to separate out the roles of political opportunism and partisanship, as opposed to economic fundamentals, in the evolution of public expenditure over time. ${ }^{48}$ To proceed, we have used times series modeling to implement a general approach: namely, that a political factor can clearly be said to influence the evolution of public choices if it can be shown to lead to departures from a dynamic path defined by the evolution of the usual economic factors for a given degree of political competition.

The empirical results indicate that while a political cycle does appear to be present in the data for real growth in Canada (over the 1870 - 2000 and 1921 - 2000 periods), the mechanism by which politics influences output is not readily apparent. There are, of course, other methods besides government spending by which political control could have been exercised - via changes in taxation or the size of the deficit, in the composition of spending, and by monetary policy - to name the likely alternatives. However, since the cycles observed are more real than nominal in nature, it is reasonable to suppose that such overtly political influences on output would require sympathetic movements in aggregate government size in the short run. Yet the data does not support any of the established theories that would explain that interconnection.

In particular, the timing of political events, the partisan nature of party politics, the minority periods of political control and the duration of partisan power do not appear to have prevented the convergence of government size to its 'fundamental' long run value (defined by the usual economic factors and the degree of political competition). Nor does there seem to be any evidence that the timing or partisan nature of party politics matter in relation to cyclical variations about that long run size. Of all of the overtly political factors, it is only the degree of political competition in both the short and the long run that affects the convergence of public expenditure to its long run path defined by economic fundamentals alone.

In addition to the importance of using a general approach to investigating the role of politics and economics in the evolution of public choices as implemented here, our results suggest several additional points that bear on the direction of future research. First, until clear evidence of a transmission mechanism is provided, it seems wise to view evidence of the existence of partisan and opportunistic political cycles in Canadian output with some caution. Perhaps the political cycle for real growth apparent in the Canadian data reflects reverse causality, from the economy to what appears to be opportunism or partisanship, an issue that deserves attention. Or perhaps the missing mechanism (other than aggregate non-interest public expenditure) is there waiting to be found. Second, the persistent significance of our measure of political competition suggests that more attention should be given to the role of such competition in forcing the matching of policy choices with underlying characteristics of the electorate, a topic that has not been studied extensively in Canada or elsewhere. ${ }^{49}$

One final aspect of our work also merits emphasis. The analysis here is based not only on the premise that political factors cannot be isolated independently of basic economic factors, but also on the premise that long

\footnotetext{
48. We recall that in this investigation, a change in perspective from that used to uncover the political business cycle is required. In particular, unlike the test of the rational partisanship hypothesis in business cycle studies, where surprise spending is important, surprise itself is not needed for evidence of a partisanship effect on government size.

49. For a study of the role of political competition (in U.S. States) that offers a similar conclusion, see Besley, Persson and Sturm (2004).
} 
and short run changes in government size are intertwined. Hence the paper distinguishes changes in size that arise over the cycle from those that arise over the longer run as part of one model that jointly determines the two types of public expenditure under political competition. An analysis of the short run involves more than simply subtracting out a mechanical trend, and the results as a whole suggest that an encompassing theory is needed to interpret and disentangle the web of connections that link political decision-making in the short and the long runs. ${ }^{50}$

50. In Ferris and Winer (2003) a spatial voting model is used to derive estimating equations for a expenditure, taxation and debt to disentangle the connections between long run and short run developments in the fiscal system as a whole . 


\section{Data Appendix}

The data used in this study come from four basic sources: Canadian Historical Statistics, for the structural variables in the earliest time period (1870 through 1921); Cansim, the statistical database maintained by Statistics Canada, for these variables in the later time period (1921-2001); Gillespie's (1991) reworking of the Federal public accounts from 1870 to 1990, updated by Ferris and Winer (2003); and Beck (1968), Campbell (1977), and the Canadian Parliamentary Guide $(1997,2002)$ for the political variables. Because the pre-1921 annual variables are often interpolations between census dates, 1921 becomes a natural point in time across which we test for the robustness of our findings. In addition, we use the 1945 to 2000 time period to see if political variables have come to matter more (or less) in contemporary times. More precise definitions and the specific sources are given below.

\section{List of Economic Variable Names and Data Sources:}

AGRIC = proportion of the labor force in agriculture. 1871-1926: Urquhart, (1993), 24-55; 1926-1995 Cansim series D31251 divided by D31252; 1996-2001: Cansim II series V2710106 divided by V2710104.

$\mathbf{D}=$ first difference operator

EXPORTS and IMPORTS = exports and imports. 1870-1926, Urquhart, (1993) Table 1.4; 1927-1960, Leacy, et al, 1983, Series G383, 384; 1961-2001: CANSIM series D14833 \& D14836.

OPEN = openness. Calculated as: (EXPORTS + IMPORTS $) /$ GNP.

GNP = gross national product in current dollars. 1870-1926: Urquhart (1993), pp. 24-25 (in millions); 1927-1938: Leacy et al (1983), Series E12, p.130; 1939-1960 Canadian Economic Observer, Historical Statistical Supplement 1986, Statistics Canada Catalogue 11-210 Table 1.4. CANSIM D11073 = GNP at market prices. 1961-2001 Cansim I D16466 = Cansim II V499724 (aggregated from quarterly data).

GOV = total government expenditure net of interest payments.1870-1989: Gillespie (1991), pp.284-286; 1990-1996: Public Accounts of Canada 1996-97: 1997-2000: Federal Government Public Accounts, Table 3 Budgetary Revenues Department of Finance web site, September 2001. To this we add the return on government investment (ROI) originally subtracted by Gillespie for his own purposes. Expenditure is net of interest paid to the private sector. Data on ROI: 1870 to 1915: Public Accounts 1917 p.64; 1915-1967: Dominion Government Revenue and Expenditure: Details of Adjustments 1915-1967 Table W-1; 1916-17 to 1966-67: Securing Economic Renewal - The Fiscal Plan, Feb 10, 1988, Table XI; 1987-88 to 1996-97: Public Accounts 1996, Table 2.2. Interest on the Debt (ID) was subtracted out (with adjustment for interest paid to the Bank of Canada (BCI) ultimately returned to the government). Data on ID: 1870-1926: Historical Statistics of Canada, Series H19-34: Federal Government budgetary expenditures, classified by function, 1867-1975; 1926-1995: Cansim D11166. 1996-2000: Cansim D18445. Finally, data for BCI: copied by hand from the Annual Reports of The Bank of Canada, Statement of Income and Expense, Annually, 1935-2000. Net Income paid to the Receiver General (for the Consolidated Revenue Acct). Note: all government data had to be converted from fiscal to calendar years.

GSIZE = the relative size of non-interest central government public expenditure, calculated as: (GOV - GRANTS) $/($ GNP)

GRANTS = Transfers to Provinces and Local Governments; 1870 - 1912: From Rowell-Sirois Commission, "Subsidies and Grants Paid to Provinces Since Confederation", Table II; 1913-1935: From Rowell-Sirois Commission, "Dominion-Provincial Subsidies and Grants", Statistical Appendix, p. 186; 1926 - 2001: Cansim label D11164 and D11165.

\section{GRANT_SHARE = GRANTS / GOV}

IMMIG = immigration numbers. 1868 - 1953: Firestone (1958), Table 83, Population, Families, Births, Deaths; Updated by Cansim D27 (1955 to 1996). Cansim Sum of X100615 (Females) plus X100614 (Men) for 1954;19972001, Cansim D27 (sum of quarters). 


\section{IMMRATIO = IMMIG/POP.}

IPIUS = Index of Industrial Production for the United States. 1870-1929: Table A15. NBER, Nutter; 1930-1970, Table A16. (BEA) Bureau of Economic Analysis;1971-1995: Cansim D360048 (1987=100);1996-2000, U.S. Department of Commerce, Business Cycle Indicators, Index of Industrial Production 1992=100.

$\mathbf{L N}=$ the $\log$ operator.

PRCNTYNG = percentage of the population below 17. 1870-1920 Leacey et al (1983). Interpolated from Census figures Table A28- 45 sum of columns 29, 30, 31, and 32 all divided by 28 (adjusted to make 1921 the same); 19212001 Cansim C892547.

$\mathbf{P}=$ GNP deflator before 1927 and GDP deflator after $(1986=100) .1870-1926$ : Urquhart, (1993), 24-25;1927-1995 (1986=100): Cansim data label D14476; 1996-2001 Cansim D140668. All indexes converted to $1986=100$ basis.

POP = Canadian population. 1870-1926: Urquhart, (1993), 24-25; 1927 - 1995: CANSIM data label D31248; 1995 - 2001: Cansim D1 (average of four quarters).

RGNP $=$ real GNP $=$ GNP/P

$\mathbf{R Y P C}=$ real income per capita $=\mathrm{GNP} /(\mathrm{P} * \mathrm{POP})$.

WWI = 1 for $1914-1918 ;=0$ otherwise. WW1after $=1$ for $1919-1921 ;=0$ otherwise.

WWII = 1 for $1939-1945 ;=0$ otherwise. WW2after $=1$ for 1946-1949; = 0 otherwise.

WWIIAftermath $=1$ from 1946 onward; $=0$ otherwise.

\section{List of Political Variable Names and Data Sources:}

The dating of each election was chosen to reflect the first year that each elected party was in power (when elections concentrate in the early summer and late fall time periods). Thus if an election was held between January and July, the election was viewed as in the actual calender year of the election. However, if the election was held between August and December, the election was attributed to the following year. On this basis:

ELAPSE $=$ the number of years since the last election.

ELECTIONYEAR $=1$ if an election year; $=0$ otherwise.

LIBERAL = 1 if governing party was the Liberal Party; $=0$ if any other (more conservative) party.

MINORITY $=1$ if the governing party was part of a minority government; $=0$ otherwise.

SEATS $=$ percentage of the seats won by the governing party.

VOTES = percentage of the popular vote won by the governing party.

\section{Data Sources for political variables:}

Beck, Murray, J. (1968). Pendulum of Power. Scarborough: Prentice Hall of Canada.

Campbell, Colin (1977). Canadian Political Facts 1945-1976. Toronto: Methuen.

Canadian Parliamentary Guide. Various years (1997, 2002).

Elections Canada (2001). Thirty Seventh General Election. Ottawa.

Scarrow, Howard A.(1962). Canada Votes: A Handbook of Federal and Provincial Election Data. Hauser Printing Company.

Web site of the Parliament of Canada: www. parl.gc.ca. 
Table 1a

Descriptive Statistics for Macroeconomic Aggregates and for Government Size Variables, 1870 - 2000

\begin{tabular}{|c|c|c|c|c|c|c|c|c|c|c|c|}
\hline & GROWTH & INFLATION & USGROWTH & USINFLAT & GSIZE & LNGSIZE & LNRYPC & LNAGRIC & LNIMRATIO & LNYOUNG & LNOPEN \\
\hline Mean & 3.69 & 2.39 & 4.06 & 1.95 & 0.097 & -2.52 & 8.67 & -1.64 & -4.9 & 3.59 & -0.83 \\
\hline Median & 4.23 & 2.23 & 5.23 & 1.73 & 0.082 & -2.5 & 8.47 & -1.09 & -4.96 & 3.65 & -0.87 \\
\hline Maximum & 16.5 & 16.7 & 22.9 & 17.98 & 0.419 & -0.87 & 10.1 & -0.54 & -2.94 & 3.88 & -0.13 \\
\hline Minimum & -12.7 & -12.3 & -24.8 & -13.89 & 0.028 & -3.57 & 7.39 & -3.61 & -6.91 & 3.14 & -1.18 \\
\hline Std. Dev. & 5.1 & 4.68 & 9.64 & 4.71 & 0.068 & 0.61 & 0.81 & 1.02 & 0.88 & 0.19 & 0.22 \\
\hline Skewness & & & & & & 0.29 & 0.16 & -0.68 & -0.42 & -0.84 & 0.99 \\
\hline $\begin{array}{r}\text { ADF (4 lags) } \\
\text { Levels }\end{array}$ & $-5.68 *$ & $-3.68 *$ & $-7.05^{*}$ & $-3.40 * *$ & 1.18 & -2.82 & 0.14 & 1.65 & -2.88 & -0.186 & -0.74 \\
\hline $\begin{array}{l}\text { ADF (4 lags) } \\
1^{\text {st }} \text { Difference }\end{array}$ & & & & & $-4.44 *$ & $-6.97 *$ & $-5.95 *$ & $-3.11 * *$ & $-5.90 *$ & $-2.55 * * *$ & $-5.13 *$ \\
\hline
\end{tabular}

Notes: $*(* *)(* * *)=$ significant at one (five)(ten) percent. ADF critical value at 5\% $=-2.88$ (MacKinnon 1996).

GSIZE = central government spending after netting out interest payment to the private sector and grants to lower levels of government.

Table 1b

Descriptive Statistics for Political Variables, 1870 - 2000

\begin{tabular}{|c|c|c|c|c|c|c|c|}
\hline & ELECTIONYEAR & ELAPSE & LIBERAL & MINORITY ${ }^{\mathrm{A}}$ & SEATS & SURPRISE $^{\AA}$ & DURATION \\
\hline Mean & 0.267 & 1.687 & 0.588 & 0.122 & 0.602 & 0.063 & 0.176 \\
\hline Median & 0 & 2 & 1 & 0 & 0.586 & 0.261 & 0 \\
\hline Maximum & 1 & 5 & 1 & 1 & 0.785 & 0.49 & 4 \\
\hline Minimum & 0 & 0 & 0 & 0 & 0.413 & -0.448 & -5 \\
\hline Std. Dev. & 0.447 & 1.409 & 0.494 & 0.329 & 0.086 & 0.361 & 2.2 \\
\hline $\begin{array}{r}\text { ADF (4 lags) } \\
\text { Levels }\end{array}$ & $-6.45^{*}$ & $-5.96 *$ & $-3.88 *$ & $-4.21 *$ & $-3.63 *$ & $-3.73 *$ & $-3.74 *$ \\
\hline
\end{tabular}

Notes: $*(* *)=$ significant at one (five) percent. ADF critical value at $1 \%=-3.48$ (MacKinnon 1996).

${ }^{\mathrm{A}}=$ Definition A for SEATS. See notes to Table 2.

SURPRISE $=\{1$-MINORITY $\}\{(1-$ SEATS $) *$ LIBERAL- $(1-$ SEATS $) *(1-$ LIBERAL $)$.

DURATION $=\{($ LIBERAL*ELAPSE $)-(1-$ LIBERAL $) * E L A P S E ~\}$. 


\section{Appendix:}

Extreme Bound Analysis Concerning the Role of Opportunistic and Partisan Political Factors in Public Expenditure

(using column (3), Table 6a)

\section{Eq0 \\ Eq1 \\ Eq2 \\ Eq3 \\ Eq4 \\ Eq5 \\ Eq6 \\ Eq7 \\ Eq8 \\ Eq9 \\ Eq10 \\ Eq11 \\ Eq12 \\ Eq13 \\ Eq14 \\ Eq15}

Average

Stand Dev

\section{Political Factors Included in Equation}

$\begin{array}{ccccc}\text { Seats } & \text { Minority } & \text { Elyear(-1) } & \text { Duration } & \text { Liberal } \\ 0.311 & & & & \\ 0.354 & 0.018 & & & \\ 0.31 & & 0.004 & & \\ 0.311 & & & 0.0005 & \\ 0.317 & & & & 0.013 \\ 0.354 & 0.018 & 0.004 & & \\ 0.355 & 0.018 & & 0.0005 & \\ 0.366 & 0.02 & & & 0.014 \\ 0.31 & & 0.004 & 0.0005 & \\ 0.316 & & 0.002 & & 0.012 \\ 0.319 & & & -0.0003 & 0.023 \\ 0.354 & 0.018 & 0.001 & 0.0005 & \\ 0.319 & & 0.016 & -0.003 & 0.023 \\ 0.375 & 0.022 & & -0.004 & 0.026 \\ 0.365 & 0.02 & 0.002 & & 0.013 \\ 0.374 & 0.022 & 0.0015 & -0.004 & 0.026 \\ & & & & \\ 0.338125 & 0.02 & 0.00275 & -0.00116 & 0.01875 \\ 0.025701 & 0.002828 & 0.004877 & 0.002114 & 0.0062735\end{array}$

\section{Extreme Bounds Analysis Table}

Variable
Name
Seats
Minority
Elyear(-1)
Duration
Liberal

$\begin{array}{ccccc}\begin{array}{c}\text { Lower } \\ \text { Bound }\end{array} & \begin{array}{c}\text { Upper } \\ \text { Bound }\end{array} & \begin{array}{c}\text { \% Sign. } \\ \text { at 1\% }\end{array} & \begin{array}{c}\text { \% Sign at } \\ \mathbf{1 0 \%}\end{array} & \begin{array}{c}\text { Standard } \\ \text { Deviation }\end{array} \\ 0.31 & 0.375 & 100 \% & 100 \% & 0.026 \\ 0.018 & 0.022 & 0 & 0 & 0.003 \\ 0.001 & 0.004 & 0 & 0 & 0.005 \\ -0.0003 & 0.0005 & 0 & 0 & 0.002 \\ 0.012 & 0.026 & 0 & 0 & 0.006\end{array}$




\section{References}

Alesina, A. (1987) "Macroeconomic Policy in a Two-Party System as a Repeated Game”, Quarterly Journal of Economics 106: 651-78.

Alesina, A., N. Roubini, with G.D. Cohen (1997) Political Business Cycles and the Macroeconomy, Cambridge: MIT Press.

Bartels, L.M., and H.E. Brady (2003) "Economic Behavior in Political Context", American Economic Review, 93: 156 - 161.

Becker, G. S. (1983) “A Theory of Competition among Pressure Groups for Political Influence”, Quarterly Journal of Economics 98, 371-400.

Besley, Timothy, Torsten Persson and Daniel Sturm (2005). "Political Competition and Economic Performance: Theory and Evidence from the United States". Unpublished.

Bird, Richard (1970). The Growth of Government Spending in Canada. Toronto: Canadian Tax Foundation.

Borcherding, T. E. (1985) "The Causes of Government Expenditure Growth: A survey of the U.S. Evidence", Journal of Public Economics 28: 359 - 382.

Borcherding, T. E., J. S. Ferris and A. Garzoni (2004) "Changes in the Real Size of Government Since 1970", in Juergen Backhaus and Richard Wagner (eds.), Kluwer Handbook in Public Finance New York: Kluwer Academic Press, 77-108.

Cameron, David (1978). "The Expansion of the Public Economy." American Political Science Review 72, 1243-1261.

Canova, Fabio (1998). "Detrending and Business Cycle Facts". Journal of Monetary Economics 41, 475-512.

Davidson, Russell and James G. MacKinnon (2004). Econometric Theory and Methods. Oxford University Press.

Dudley, L.and U. Witt (2004) "Arms and the Man: World War I and the Rise of the Welfare State", University of Montreal manuscript, 35 pages.

Erlandsson, M. (2004) "Partisan differences in Swedish macroeconomics policy" Public Choice 120: 205-220.

Engle, R.F. and C.W.J. Granger (1987) "Co-integration and Error Correction: Representation, Estimation, and Testing," Econometrica 55, 2: 251-276.

Eviews 5.1, Quantitative Micro Software, 2004.

Ferris, J. S. and E. G. West (1996) "Testing Theories of Real Government Size: U.S. Experience, 1959 1989," Southern Economic Journal, 62: 537-553.

Ferris, J. S. and S. Winer (2003) "Searching for Keynes: With Application to Canada, 1870 - 2000", CESifo Working Paper No. 1016, 35 pages.

Gillespie, W. I. (1991) Tax, Borrow and Spend: Financing Federal Spending in Canada, 1867-1990. Carleton Library Series, no. 170. Ottawa: Carleton University Press.

Gregory, A. W. and B. E. Hansen (1996) "Residual-Based Tests for Cointegration in Models with Regime Shifts," Journal of Econometrics 70, 1: 99-126.

Haynes S.E. and J. A. Stone (1990) "Political Models of the Business Cycle Should Be Revived" Economic Inquiry, 28 ,3: 442-65.

Heckelman, J.C. (2002) "Electoral Uncertainty and the macroeconomy: the evidence from Canada", Public Choice 113: 179-189.

Hibbs, D. (1977) "Political Parties and Macroeconomic Policy”, American Political Science Review 71: 1467- 87.

Johansen, S. (1991). "Estimation and Hypothesis testing of Cointegration Vectors in Gaussian Vector Autoregressive Models." Econometrica 59, 1551-1580. 
Johansen, S. (1995). Likelihood-based Inference in Cointegrated Vector Autoregression Models, Oxford University Press.

Kau, J. B. and P. H. Rubin (1981), "The Size of Government", Public Choice 37: 261-74.

Kayser, M. A. (2005). "Who Surfs, Who Manipulates? The Determinants of Opportunistic Election Timing and Electorally Motivated Economic Intervention." American Political Science Review 99(1), 17-27.

Kneebone, R. D. and K. J. McKenzie (1999) Past (In) Discretions: Canadian Federal and Provincial Fiscal Policy, Toronto: University of Toronto Press.

Kneebone, R.D. and K.J. McKenzie (2001) "Electoral and Partisan Cycles in Fiscal Policy: An examination of Canadian provinces" International Tax and Public Finance 8: 753-74.

Kontopolous, Y. and R. Perotti (1999) "Government Fragmentation and Fiscal Policy Outcomes: Evidence from OECD Countries" in Poterba J. and J. von Hagen, eds. Fiscal Institutions and Fiscal Performance, Chicago: University of Chicago Press, 81-102.

Legrenzi, G. (2004) "The Displacement Effect in the Growth of Governments" Public Choice 120: 191-204.

Levitt, S. D. and J. M. Poterba (1999) “Congressional Distributive Politics and State Economic Performance", Public Choice 99: 185 - 215.

MacKinnon, J. G. (1996) "Numerical Distribution Functions for Unit Root and Cointegration Tests", Journal of Applied Econometrics 11, 6: 601-618.

Mueller, D.C. (1989) Public Choice II, Cambridge: Cambridge University Press.

Nordhaus, W. (1975) “The Political Business Cycle”, Review of Economic Studies 42: 169-90.

Peacock, A. and J. Wiseman (1961) The Growth of Public Expenditure in the United Kingdom, Princeton: Princeton University Press.

Persson, Torsten, Gerard Roland and Guido Tabellini (2004). "How do Electoral Rules Shape Party Structures, Government Coalitions, and Economic Policies." CESifo Working Paper No. 1115, January 2004.

Persson, Torsten and Guido Tabellini (2003). "Do Electoral Cycles Differ Across Political Systems?" Working Paper 232, IGIER, University of Bocconi, March.

Quantitative Micro Software. Eviews 5.1.2004.

Reid, B. (1998) "Endogenous Elections, electoral budget cycles and Canadian provincial governments", Public Choice 97, 1: 35-48.

Reuber, G. (1978) "Canadian Economic Policy: Some Perspectives suggested by the work of Harry Johnson", Canadian Journal of Economics 11, 4: S121-40.

Remmer K. L. and E. Wibbels (2000) "The Subnational Politics of Economic Adjustment", Comparative Political Studies 33, 4: 419-51.

Rodrik, D. (1998) “Why do more open economies have bigger governments?” Journal of Political Economy 106, 997-1032.

Saikkonen, P. (1991). "Asymptotically Efficient Estimation of Cointegration Regressions", Econometric Theory 7, 1: 1-21.

Serletis, A. and P.C. Afxentiou (1998) "Electoral and Partisan Cycle Regularities in Canada" Canadian Journal of Economics 31, 1: 28-46.

Schneider, F. and W. W. Pommerehne (1980) "Politico-Economic Interactions in Australia: Some Empirical Evidence", Economic Record 56, 153: 113-31.

Stigler, G.J. (1972) "Economic Competition and Political Competition", Pubic Choice, 13: 91106.

Urquhart, M.C., 1993, Gross National Product, 1870-1926. McGill-Queen's University Press.

Winer, Stanley. L. (1986a). “ Money and Politics in a Small Open Economy”. Public Choice 51,2: 221-39.

Winer, Stanley. L. (1986b). "The Role of Exchange Rate Flexibility in the International Transmission of Inflation in Long and Shorter Runs: Canada 1953 to 1981." Canadian Journal of Economics, 19, 62-86. 


\section{CESifo Working Paper Series}

(for full list see www.cesifo-group.de)

1581 Astri Muren and Sten Nyberg, Young Liberals and Old Conservatives - Inequality, Mobility and Redistribution, November 2005

1582 Volker Nitsch, State Visits and International Trade, November 2005

1583 Alessandra Casella, Thomas Palfrey and Raymond Riezman, Minorities and Storable Votes, November 2005

1584 Sascha O. Becker, Introducing Time-to-Educate in a Job Search Model, November 2005

1585 Christos Kotsogiannis and Robert Schwager, On the Incentives to Experiment in Federations, November 2005

1586 Søren Bo Nielsen, Pascalis Raimondos-Møller and Guttorm Schjelderup, Centralized vs. De-centralized Multinationals and Taxes, November 2005

1587 Jan-Egbert Sturm and Barry Williams, What Determines Differences in Foreign Bank Efficiency? Australian Evidence, November 2005

1588 Steven Brakman and Charles van Marrewijk, Transfers, Non-Traded Goods, and Unemployment: An Analysis of the Keynes - Ohlin Debate, November 2005

1589 Kazuo Ogawa, Elmer Sterken and Ichiro Tokutsu, Bank Control and the Number of Bank Relations of Japanese Firms, November 2005

1590 Bruno Parigi and Loriana Pelizzon, Diversification and Ownership Concentration, November 2005

1591 Claude Crampes, Carole Haritchabalet and Bruno Jullien, Advertising, Competition and Entry in Media Industries, November 2005

1592 Johannes Becker and Clemens Fuest, Optimal Tax Policy when Firms are Internationally Mobile, November 2005

1593 Jim Malley, Apostolis Philippopoulos and Ulrich Woitek, Electoral Uncertainty, Fiscal Policy and Macroeconomic Fluctuations, November 2005

1594 Assar Lindbeck, Sustainable Social Spending, November 2005

1595 Hartmut Egger and Udo Kreickemeier, International Fragmentation: Boon or Bane for Domestic Employment?, November 2005

1596 Martin Werding, Survivor Benefits and the Gender Tax Gap in Public Pension Schemes: Observations from Germany, November 2005 
1597 Petra Geraats, Transparency of Monetary Policy: Theory and Practice, November 2005

1598 Christian Dustman and Francesca Fabbri, Gender and Ethnicity - Married Immigrants in Britain, November 2005

1599 M. Hashem Pesaran and Martin Weale, Survey Expectations, November 2005

1600 Ansgar Belke, Frank Baumgaertner, Friedrich Schneider and Ralph Setzer, The Different Extent of Privatisation Proceeds in EU Countries: A Preliminary Explanation Using a Public Choice Approach, November 2005

1601 Jan K. Brueckner, Fiscal Federalism and Economic Growth, November 2005

1602 Steven Brakman, Harry Garretsen and Charles van Marrewijk, Cross-Border Mergers and Acquisitions: On Revealed Comparative Advantage and Merger Waves, November 2005

1603 Erkki Koskela and Rune Stenbacka, Product Market Competition, Profit Sharing and Equilibrium Unemployment, November 2005

1604 Lutz Hendricks, How Important is Discount Rate Heterogeneity for Wealth Inequality?, November 2005

1605 Kathleen M. Day and Stanley L. Winer, Policy-induced Internal Migration: An Empirical Investigation of the Canadian Case, November 2005

1606 Paul De Grauwe and Cláudia Costa Storti, Is Monetary Policy in the Eurozone less Effective than in the US?, November 2005

1607 Per Engström and Bertil Holmlund, Worker Absenteeism in Search Equilibrium, November 2005

1608 Daniele Checchi and Cecilia García-Peñalosa, Labour Market Institutions and the Personal Distribution of Income in the OECD, November 2005

1609 Kai A. Konrad and Wolfgang Leininger, The Generalized Stackelberg Equilibrium of the All-Pay Auction with Complete Information, November 2005

1610 Monika Buetler and Federica Teppa, Should you Take a Lump-Sum or Annuitize? Results from Swiss Pension Funds, November 2005

1611 Alexander W. Cappelen, Astri D. Hole, Erik Ø. Sørensen and Bertil Tungodden, The Pluralism of Fairness Ideals: An Experimental Approach, December 2005

1612 Jack Mintz and Alfons J. Weichenrieder, Taxation and the Financial Structure of German Outbound FDI, December 2005

1613 Rosanne Altshuler and Harry Grubert, The Three Parties in the Race to the Bottom: Host Governments, Home Governments and Multinational Companies, December 2005 
1614 Chi-Yung (Eric) Ng and John Whalley, Visas and Work Permits: Possible Global Negotiating Initiatives, December 2005

1615 Jon H. Fiva, New Evidence on Fiscal Decentralization and the Size of Government, December 2005

1616 Andzelika Lorentowicz, Dalia Marin and Alexander Raubold, Is Human Capital Losing from Outsourcing? Evidence for Austria and Poland, December 2005

1617 Aleksander Berentsen, Gabriele Camera and Christopher Waller, Money, Credit and Banking, December 2005

1618 Egil Matsen, Tommy Sveen and Ragnar Torvik, Savers, Spenders and Fiscal Policy in a Small Open Economy, December 2005

1619 Laszlo Goerke and Markus Pannenberg, Severance Pay and the Shadow of the Law: Evidence for West Germany, December 2005

1620 Michael Hoel, Concerns for Equity and the Optimal Co-Payments for Publicly Provided Health Care, December 2005

1621 Edward Castronova, On the Research Value of Large Games: Natural Experiments in Norrath and Camelot, December 2005

1622 Annette Alstadsæter, Ann-Sofie Kolm and Birthe Larsen, Tax Effects, Search Unemployment, and the Choice of Educational Type, December 2005

1623 Vesa Kanniainen, Seppo Kari and Jouko Ylä-Liedenpohja, Nordic Dual Income Taxation of Entrepreneurs, December 2005

1624 Lars-Erik Borge and Linn Renée Naper, Efficiency Potential and Efficiency Variation in Norwegian Lower Secondary Schools, December 2005

1625 Sam Bucovetsky and Andreas Haufler, Tax Competition when Firms Choose their Organizational Form: Should Tax Loopholes for Multinationals be Closed?, December 2005

1626 Silke Uebelmesser, To go or not to go: Emigration from Germany, December 2005

1627 Geir Haakon Bjertnæs, Income Taxation, Tuition Subsidies, and Choice of Occupation: Implications for Production Efficiency, December 2005

1628 Justina A. V. Fischer, Do Institutions of Direct Democracy Tame the Leviathan? Swiss Evidence on the Structure of Expenditure for Public Education, December 2005

1629 Torberg Falch and Bjarne Strøm, Wage Bargaining and Political Strength in the Public Sector, December 2005

1630 Hartmut Egger, Peter Egger, Josef Falkinger and Volker Grossmann, International Capital Market Integration, Educational Choice and Economic Growth, December 2005 
1631 Alexander Haupt, The Evolution of Public Spending on Higher Education in a Democracy, December 2005

1632 Alessandro Cigno, The Political Economy of Intergenerational Cooperation, December 2005

1633 Michiel Evers, Ruud A. de Mooij and Daniel J. van Vuuren, What Explains the Variation in Estimates of Labour Supply Elasticities?, December 2005

1634 Matthias Wrede, Health Values, Preference Inconsistency, and Insurance Demand, December 2005

1635 Hans Jarle Kind, Marko Koethenbuerger and Guttorm Schjelderup, Do Consumers Buy Less of a Taxed Good?, December 2005

1636 Michael McBride and Stergios Skaperdas, Explaining Conflict in Low-Income Countries: Incomplete Contracting in the Shadow of the Future, December 2005

1637 Alfons J. Weichenrieder and Oliver Busch, Artificial Time Inconsistency as a Remedy for the Race to the Bottom, December 2005

1638 Aleksander Berentsen and Christopher Waller, Optimal Stabilization Policy with Flexible Prices, December 2005

1639 Panu Poutvaara and Mikael Priks, Violent Groups and Police Tactics: Should Tear Gas Make Crime Preventers Cry?, December 2005

1640 Yin-Wong Cheung and Kon S. Lai, A Reappraisal of the Border Effect on Relative Price Volatility, January 2006

1641 Stefan Bach, Giacomo Corneo and Viktor Steiner, Top Incomes and Top Taxes in Germany, January 2006

1642 Johann K. Brunner and Susanne Pech, Optimum Taxation of Life Annuities, January 2006

1643 Naércio Aquino Menezes Filho, Marc-Andreas Muendler and Garey Ramey, The Structure of Worker Compensation in Brazil, with a Comparison to France and the United States, January 2006

1644 Konstantinos Angelopoulos, Apostolis Philippopoulos and Vanghelis Vassilatos, RentSeeking Competition from State Coffers: A Calibrated DSGE Model of the Euro Area, January 2006

1645 Burkhard Heer and Bernd Suessmuth, The Savings-Inflation Puzzle, January 2006

1646 J. Stephen Ferris, Soo-Bin Park and Stanley L. Winer, Political Competition and Convergence to Fundamentals: With Application to the Political Business Cycle and the Size of Government, January 2006 